\title{
AÇÃO DE BEBIDAS COM TEOR ÁCIDO SOBRE A \\ PERMEABILIDADE DENTINÁRIA - ESTUDO IN VITRO
}

\section{MARIA CECÍLIA RIBEIRO DE MATTOS}

Dissertação apresentada à faculdade de Odontologia de Bauru da universidade de São Paulo, como parte dos requisitos para a obtenção do título de Mestre em Odontologia - Área de Concentração Dentística Restauradora.

Bauru - SP

2005 


\section{AÇÃO DE BEBIDAS COM TEOR ÁCIDO SOBRE A \\ PERMEABILIDADE DENTINÁRIA - ESTUDO IN VITRO}

\section{MARIA CECÍLIA RIBEIRO DE MATTOS}

Dissertação apresentada à faculdade de Odontologia de Bauru da universidade de São Paulo, como parte dos requisitos para a obtenção do título de Mestre em Odontologia - Área de Concentração Dentística Restauradora.

Orientador: Prof. Dr. José Carlos Pereira

Bauru - SP

2005 
M436a

Mattos, Maria Cecília Ribeiro de Ação de bebidas com teor ácido sobre a permeabilidade dentinária - estudo in vitro / Maria Cecília Ribeiro de Mattos -- Bauru, 2005.

99 p.: il.; $30 \mathrm{~cm}$.

Dissertação (Mestrado) -- Faculdade de Odontologia de Bauru, Universidade de São Paulo.

Orientador: Prof. Dr. José Carlos Pereira

Autorizo, exclusivamente pra fins acadêmicos e científicos, a reprodução total ou parcial desta tese, por processo fotocopiadores oe/ou meios eletrônicos.

Assinatura do autor:

Data:

Comitê de Ética da FOB-USP

Protocolo n. ${ }^{\circ:}$ 256/2002

Data: $27 / 11 / 2002$ 


\title{
MARIA CECÍLIA RIBEIRO DE MATTOS
}

\author{
Nascimento $\quad 14$ de abril de 1976 \\ Dracena - SP \\ Filiação \\ Raul de Mattos \\ Maria Aparecida Ribeiro Pinto de Mattos \\ 1996 - $1999 \quad$ Curso de Odontologia \\ Faculdade de Odontologia de Bauru \\ Universidade de São Paulo \\ 2001 - 2002 Curso de Especialização em Dentística Restauradora \\ Faculdade de Odontologia de Bauru \\ Universidade de São Paulo \\ 2003 - 2005 Curso de Pós-graduação em Dentística Restauradora \\ em nível de Mestrado \\ Faculdade de Odontologia de Bauru \\ Universidade de São Paulo
}

Associações $\quad$ GBPD - Grupo Brasileiro de Professores de Dentística 


\section{DEDICATÓRIA}

Dedico este trabalho a meus pais. Sem eles, com certeza, não conseguiria realizar mais este sonho! 
"A vida não passa de um instante, mas basta este instante para empreendermos coisas eternas."

E. Bersot 


\section{Agradeço de forma especial}

Ao meu orientador, Prof. Dr. José Carlos Pereira. Muito obrigada por sua dedicação, pelo seu tempo, mesmo quando na ausência dele, pelos ensinamentos transmitidos, pela paciência...(e que paciência!)e, principalmente, muito obrigada por acreditar em mim!

Tudo isso, professor, foi essencial à conclusão do nosso trabalho! 


\section{Agradeço de Coração}

Aos meus pais, Raule Cidinha! As palavras, nesse momento, faltam! Porque não há o que possa ser dito ou escrito que realmente traduza o imenso amor e gratidão que tenho por vocês! Obrigada, meus pais, por estarem semrpe ao meu lado!

Aos meus irmãos, Raul(meu "Precioso Lindo"!) e Ana Zilda, pessoas que amo muito e com quem divido a felicidade que hoje sinto pela finalização dessa etapa!

Aos meus tios e primos, que sei que torcem por mim, que vibram comigo! Obrigada pelos tantos 6ons momentos que passamos juntos!

À Mónica que, desde o nosso curso de Especialização, esteve sempre ao meu lado. Que, indubitavelmente, também foi essencial - e eu já disse isso a você, nãoé, Monique?! - á conclusão desse trabalho! O6rigada por me "agüentar" por tanto tempo!

Você sabe o quanto você é importante, não?! Por isso, peço, mesmo de longe, continue por perto, está bem?!

Às minhas amigas, que moram no meu coração, Kate e Lucimara. A vocês, que sempre, desde minha graduação, estiveram comigo e acompanharam passo a passo 
toda essa etapa da minha vida, dizer "obrigada" é muito pouco pelo "tudo" que sempre fizeram! A vocês, minha eterna gratidão!

À Susy, que é minha friend querida, muito querida! Infelizmente, friend, nem sempre você pode estar ao meu lado. Infelizmente mesmo! Mas, apesar de preferir que você realmente esteja mais presente no meu dia a dia, saiba que, hoje, mesmo nos poucos momentos que podemos estar juntas, você ainda consegue ser a minha "dear friend"! O6rigada por ainda estar ao meu lado!

À Fernanda, que, a cada dia, me surpreende com a grandeza de suas atitudes. Obrigada, não somente por sua ajuda para a conclusão deste tra6alho, mas pelo fato de saber que posso contar com você! Obrigada, Fer!

À Mirian, que sempre me socorre nos meus momentos de baixo astral! Obrigada por me escutar, obrigada por me fazer rir!

À Dani, minha mais nova amiga, pelo carinho, pela atenção, por sua amizade.

À Renata, pela eterna paciência! Pelo apoio imprescindível à realização desta dissertação. 
A você, Bruno, pela disponibilidade em me ajudar em meus trabalhos! $\mathcal{N}$ em tenho como agradecê-lo pela gentileza e presteza.

À turma de mestrado em Dentística, Adilson, Adriana (Obrigada, Dri!), Aninha, André, Débora, Juliana, Miguel, Paty, Safira, Tici pela grande amizade e por compartilharem comigo importantes momentos da minha vida.

À turma de doutorado em Dentística, Ana Raquel, Angélica, Anuradha, Diego, Eduardo, Fabiano, Flávia, Leonardo, Luiz, Margarete, Sérgio, Terezinha. Ao Renato, doutorando em Materiais Dentários. Obrigada a todos vocês pelo constante apoio na conclusão do meu trabalho! 


\section{Minha profunda Gratidão:}

Ao Prof. Dr. José Mondelli, minha eterna admiração pelo exemplo profissional acadêmico e pessoal. Foi em pessoas como o senhor, professor, em quem me espelhei quando decidi pela carreira de docente! Que Deus esteja sempre ao seu Cado!

À Prof. Dra. Maria Fidela de Lima Navarro, pessoa que admiro muito e tenho grande respeito.

Ao Prof. Dr. Mário Honorato da Silva e Souza Jr., por quem tenho grande carinho e que muito contribuiu, com sua experiência profissional, para que pudesse estar aqui nesse momento.

À Prof. Dra. Maria Teresa Atta, por quem tenho grande carinho por ter sido minha orientadora em meu curso de especialização! Obrigada pelos conhecimentos transmitidos.

Ao Prof. Dr. Ricardo Marins de Carvalho, por sua amizade e, principalmente, por sua habilidade em ensinar! 
Ao Prof. Dr. Carlos Eduardo Francischone, pelo seu elevado espírito docente.

- Ao Profs Drs. Rafael Lia Mondelli e Paulo Francischone, pelos conhecimentos transmitidos.

Ao Prof. Dr. Eduardo Batista Franco por sua capacidade de transformar os mínimos detalhes em perfeita simetria. 


\section{Agradecimentos}

Aos funcionários do Departamento de Dentística, Rita, Ângela, Zuleica, Nélson e

Karen,, pelo apoio e colaboração não somente no decorrer do curso de Mestrado, mas desde minha graduação, que tive a felicidade de realizar nessa mesma instituição de ensino.

Aos professores e funcionários da disciplina de Histologia pelo carinho e valiosa colaboração neste trabalho. A Tânia pela amizade, pelo carinho, pela incansável disponibilidade! Ao Professor Gerson, pelo apoio. Aos estagiários Angélica, Juliana pela amizade e convívio tão agradável no laboratório e ajuda.

À Thelma, funcionária do Departamento de Bioquímica, pela atenção a mim dispensada quando assim necessário! Obrigada pelo carinho que sempre teve por mim!

Aos funcionários da Pós-Graduação, Giane, Margarete, Letícia, Cleusa, Eduardo, Jéferson e Mírian, pelo profissionalismo, carinho e gentileza em todos os momentos. Obrigada também pela paciência, pela disponibilidade de vocês! Saibam que, sem vocês, certamente, não conseguiria vencer esta etapa! 
Ao Prof. Dr. José Roberto Pereira Lauris, por me instruir na realização da análise estatística deste trabalho.

Aos funcionários da biblioteca pela solicitude e profissionalismo sempre demonstrados.

Aos funcionários do Laboratório de Química da Faculdade de Ciências da Universidade Paulista Júlio de Mesquita Filho - VNESP - Antonio Carlos Feitoza e Fernando Strutzel, pela gentileza e grande ajuda para o desenvolvimento de parte deste trabalho de pesquisa.

À CAPES, pelo apoio financeiro, tornando exeqüível este trabalho.

A todas as pessoas que, de alguma maneira, direta ou indiretamente, contribuíram com esta conquista que hoje tenho concretizada!

MEUS SINCEROS AGRADECIMENTOS. 


\section{SUMÁRIO}



1- INTRODUÇÃO --- 01



2.1 Complexo dentinopulpar ---_- 06

2.1.1 Dentina --- 08

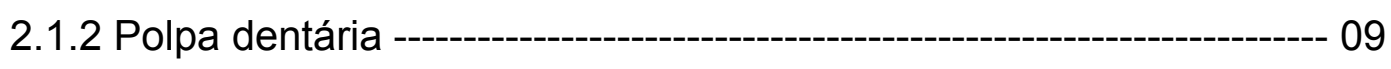

2.2 Hiperestesia dentinária--- 12

2.2.1 Incidência e Prevalência ------ 12

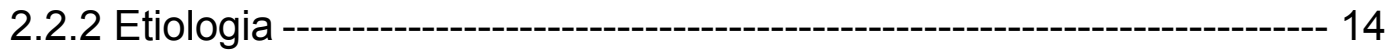

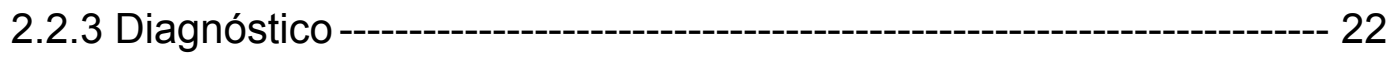

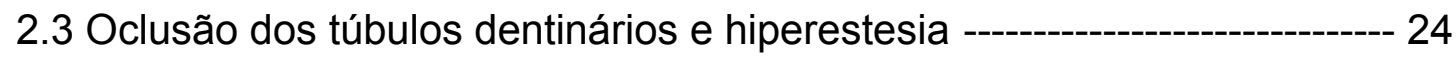

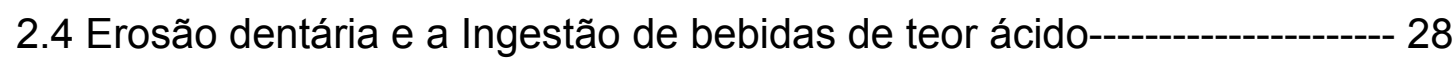

3.- PROPOSIÇÃO

4.-MATERIAL E MÉTODOS- 38

4.1 Seleção dos dentes e obtenção dos espécimes ----------------- 39

4.2 Sistema de medição da condutividade hidráulica ---------------------------- 42

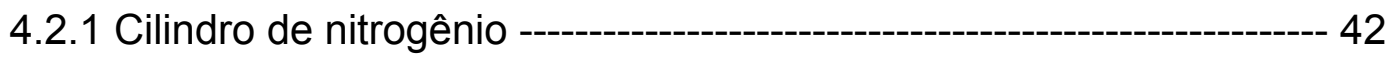

4.2.2 Câmara de pressão --- 43

4.2.3 Sistema de capilar de polietileno e componentes para a leitura ---- 44

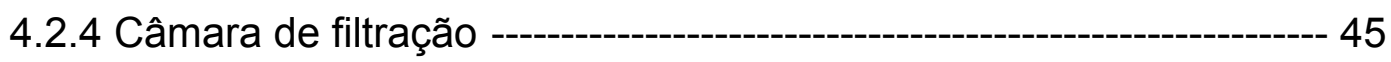

4.3 Materiais e condições experimentais --- 46

4.4 Análise dos resultados de Condutividade Hidráulica ------------------- 50

4.5 Preparação das amostras para Microscopia Eletrônica de Varredura --- 52

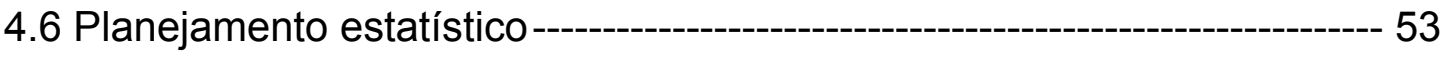

5- RESULTADOS ---_- 54

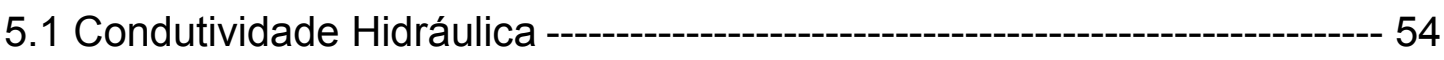

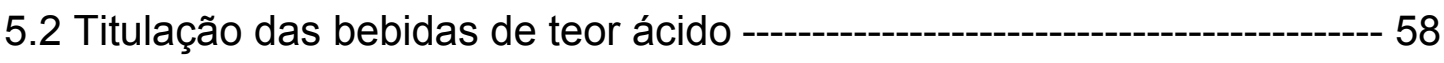

5.3 Microscopia Eletrônica de Varredura --_- 61

6- DISCUSSÃO-- 64

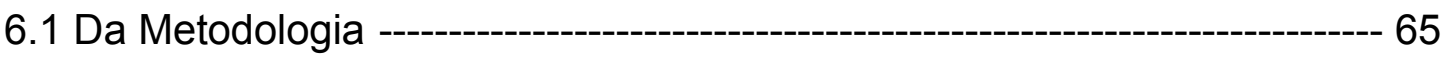


6.2 Dos Resultados --------------------------------------------------------------------------- 72

7- CONCLUSÕES -- 79



REFERÊNCIAS BIBLIOGRÁFICAS -------------------------------------------------------- 85

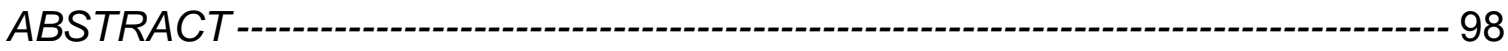




\section{LISTA DE FIGURAS}

Figura 1 Dente extraído, fixado à base de resina com cera pegajosa ---_-a----- 40

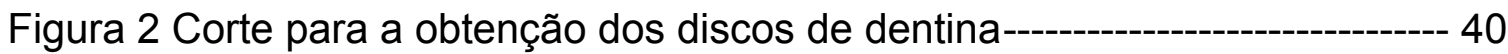

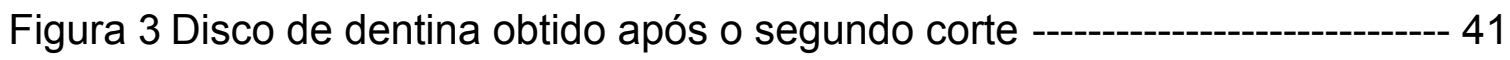

Figura 4.- Representação esquemática do sistema utilizado para a medição da condutividade hidráulica da dentina. (adaptado de Pashley \& Galloway ${ }^{69}$ ) -- 42 Figura 5- Bebidas com teor ácido

Figura 6.- Superfície não tratada, com aparência característica da smear layer 62

Figura 7- Grau de exposição tubular nos espécimes tratados com o suco artificial por $3(A)$ e 5 minutos $(B)$, respectivamente 62

Figura 8 - Remoção da smear layer pelo suco de laranja natural, sendo mais acentuada após 5 minutos $(\mathrm{B})$ 62

Figura 9-Espécimes representativos da Coca Cola light 63

Figura 10 - Espécimes representativos da Coca Cola regular mostrando exposição mais acentuada dos túbulos dentinários, para ambos os tempos (A e B, respectivamente) 63

Figura 11 Discos tratados com cerveja após 3 (A) e 5 minutos (B) 63 


\section{LISTA DE TABELAS}

Tabela 1- Relação das bebidas testadas no experimento

Tabela 2- Percentual médio e desvio padrão da permeabilidade dentinária (Lp) após a aplicação de diferentes bebidas com teor ácido (Duncan, $p<0,05)$. 56

Tabela 3- Variação, em pontos percentuais, da condutividade hidráulica para o tempo de 3 minutos, com resultado do teste de Duncan $(p<0,05)--57$

Tabela 4.- Variação, em pontos percentuais, da condutividade hidráulica para o tempo de 5 minutos, com resultado 58

Tabela 5- Volume necessário da base $\mathrm{KOH}$ (em $\mathrm{ml}$ ) para $10 \mathrm{ml}$ das bebidas de teor ácido atingirem $\mathrm{pH} \sim 7$, 60 


\section{LISTA DE GRÁFICOS}

Gráfico 1- Variação, em pontos percentuais, da condutividade hidráulica em 3 minutos 57

Gráfico 2-Variação, em pontos percentuais, da condutividade hidráulica para o tempo de 5 minutos 58

Gráfico 3- Volume (em $\mathrm{ml})$ de solução alcalina $(\mathrm{KOH})$ necessária para 10ml das bebidas com teor ácido atingirem $\mathrm{pH} \sim 7,0$. 60 


\section{LISTA DE ABREVIATURAS E SÍMBOLOS}




RESUMO 


\section{RESUMO}

A hiperestesia dentinária não é uma condição de dor incomum na odontologia. Porém, mesmo diante dos inúmeros trabalhos efetuados, sua compreensão ainda não é total. A teoria da Hidrodinâmica, que melhor explica a ocorrência dessa situação clínica, baseia-se no movimento do fluido dentinário através dos túbulos como provável desencadeador da dor ${ }^{10}$, 26, O estudo do consumo de bebidas de alto teor ácido e seus efeitos sobre as estruturas dentárias é também bastante explorado pelas pesquisas em geral ${ }^{4,20,41,47}$. O presente trabalho analisou, in vitro, as alterações da permeabilidade dentinária frente à exposição à Coca Cola regular, Coca Cola light, sucos de laranja natural e artificial e Cerveja. Realizou-se o teste da condutividade hidráulica em 50 discos de dentina, divididos em 5 grupos correspondentes às bebidas analisadas, avaliados após 3 e 5 minutos do contato com cada bebida. Os resultados foram analisados estatisticamente através do teste de variação e teste de Duncan. Os resultados mostraram que: as bebidas de teor ácido estudadas exerceram efeito sobre a condutividade hidráulica de dentina; não houve diferença estatisticamente significante entre os valores condutividade hidráulica obtidos após 3 e 5 minutos; para os dois tempos estudados, os sucos de laranja exerceram efeito significantemente maior na condutividade hidráulica da dentina do que as bebidas do tipo "cola". Os efeitos destas e da Cerveja foram estatisticamente semelhantes. 


\section{1- INTRODUÇÃO}




\section{1- INTRODUÇÃO}

A dor é o evento clínico mais desconfortável pelo qual pode passar o paciente e de mais difícil solução ao profissional que o trata, visto a necessidade do diagnóstico adequado e rápido a fim de que se minimize o mais prontamente possível toda essa situação de incômodo que a dor pode gerar $^{74}$.

$\mathrm{Na}$ Odontologia, uma situação que geralmente leva o paciente a desenvolver quadros de dor é a hiperestesia dentinária, conseqüência da exposição da dentina ao meio bucal, a qual deveria estar protegida por esmalte ao meio bucal. São várias as causas que podem estar envolvidas para a ocorrência dessa alopatia, dentre elas, a erosão química. Esta pode estar relacionada a inúmeros fatores, divididos em intrínsecos e extrínsecos. Entre os fatores intrínsecos, temos a regurgitação, que pode estar associada a doenças gastrointestinais ou de origem psicosomática 4,5,47,92,101. Com relação aos extrínsecos, o hábito do paciente em consumir alimentos predominantemente ácidos que podem atacar as superfícies dentárias, corresponde ao fator mais amplamente discutido pela literatura atual ${ }^{47}$. $45,51,58$

O elevado consumo de bebidas com teor ácido pode estar relacionado ao aumento da prevalência de lesões de erosão dentária atualmente, daí o interesse do presente trabalho em estudar a relação dessas bebidas com o aumento da permeabilidade dentinária e possível ocorrência de hiperestesia na região de dentina exposta. A prevalência 
dessa condição é, no entanto, variável de acordo com o tipo de exame realizado para sua averiguação bem como população analisada ${ }^{16,87}$.

A ação de bebidas carbonatadas como a Coca Cola e de sucos cítricos tem sido amplamente exploradas pela literatura com relação ao potencial erosivo apresentado por tais soluções bem como devido ao elevado consumo pela população em geral ${ }^{14,20,49,58,83,85}$. Como característica geral, essas bebidas apresentam um baixo $\mathrm{pH}$ em virtude de possuírem algum componente ácido entre seus ingredientes. Entretanto, como confirmam alguns estudos $14,19,20,41,50,58$, não somente os valores de $\mathrm{pH}$ interferem no potencial erosivo de uma substância, mas também sua capacidade tampão, ou seja, a capacidade que essa apresenta de manter seu $\mathrm{pH}$ ácido inicial diante da adição de soluções básicas, que buscam transformá-la em uma solução com pH neutro. A ação dessas substâncias, apesar de amplamente correlacionada à ocorrência de lesões de erosão, conforme citado anteriormente, pouco é relacionada ao aumento da permeabilidade dentinária.

Segundo a Teoria da Hidrodinâmica, amplamente estudada por autores como BRÄNNSTRÖN ${ }^{10}, \mathrm{PASHLEY}^{73}$, a permeabilidade dentinária é o fator primordial na ocorrência da hiperestesia dentinária. Segundo essa teoria, a alteração da hidrodinâmica dos fluidos no interior dos túbulos, nas regiões em que se tem dentina exposta, poderia causar sensibilidade, já que, frente a um estímulo, este material se movimentaria através da estrutura dentinária, sendo transmitido à polpa, um tecido amplamente 
vascularizado e enervado, provocando a sensação de dor ao referido estímulo ${ }^{10,26}$.

Trabalhos indicam que o estudo da permeabilidade dentinária in vitro é primordial à sua compreensão, por permitir o controle de variáveis importantes, além de possibilitar um maior domínio das diferenças existentes na estrutura da própria dentina, que podem interferir de maneira negativa nos resultados de um estudo ${ }^{71}$.

Apesar dos inúmeros estudos 4,34,64,74,77,80,100 que abordam a hiperestesia dentinária, bem como suas prováveis causas e terapia de escolha, ainda se trata de problema pouco compreendido no universo da dor de origem dentária. A permeabilidade dentinária, da mesma forma, tem sido pouco explorada por pesquisas no que se refere à sua possível relação com o consumo de bebidas com teor ácido.

Sendo a dieta um fator a ser considerado como potente causador da exposição dentinária pela erosão dentária, o presente estudo teve por objetivo avaliar a permeabilidade dentinária após contato com algumas bebidas de teor ácido comumente presentes na dieta da população em geral e, desse modo, verificar a possível relação existente entre o consumo dessas bebidas e a ocorrência da hipererestesia dentinária em função do aumento da permeabilidade dentinária. 
2- REVISÃO DE LITERATURA 


\section{2- REVISÃO DE LITERATURA}

A hiperestesia dentinária é freqüentemente definida como sendo uma resposta exagerada ou uma dor transitória relacionada à exposição da dentina a estímulos químicos, táteis, térmicos ou osmóticos provenientes do meio bucal, os quais normalmente não causariam resposta em um dente saudável, sem evidência de outro defeito ou patologia. Esta exposição pode ser resultante da perda de esmalte por processos de abfração, atrição, erosão ou abrasão e também pelo desnudamento da superfície radicular por recessão gengival ou tratamento periodontal ${ }^{87}$.

Para entendermos, porém, os mecanismos através dos quais buscase explicar a ocorrência desta entidade, faz-se necessário o conhecimento mais detalhado do complexo dentinopulpar, bem como dos fenômenos que nele ocorrem e podem levar às sensações inerentes ao quadro de dor e hiperestesia dentinária.

\subsection{Complexo dentinopulpar}

A natureza proveu o dente com características muito especiais. Além das peculiaridades próprias do cemento e do esmalte, possui ainda as particularidades inerentes ao complexo dentinopulpar, as quais são bastante complexas e dinâmicas $^{76}$.

Os principais componentes do complexo dentinopulpar são a dentina e a polpa, que atuam conjuntamente, podendo ser consideradas, portanto, como uma entidade funcional única ${ }^{78}$. Tiveram o mesmo processo de 
formação embrionária e, também pelo fato de encontrarem-se ligadas, dentina e polpa compartilham todos os fenômenos fisiológicos que ocorrem em função do amadurecimento do órgão dental ${ }^{57,76,78}$, sendo também correto imaginar, dessa forma, que quaisquer eventos patológicos que acometam uma, terá conseqüências para a outra.

O íntimo relacionamento entre a dentina e a polpa pode ser evidenciado desde o processo de desenvolvimento do órgão dentário, quando as células odontoblásticas da polpa são responsáveis pela formação até a organização e maturação de fibras colágenas e proteoglicanas para a constituição de dentina. Em contrapartida, o início da dentinogênese determina, nesse período, a diferenciação da papila dentária em polpa ${ }^{97}$ e, à medida que o processo de formação e maturação do órgão dentário evolui, a interação entre ambas torna-se ainda mais explícita. Durante a deposição da matriz, responsável pela formação da dentina, os odontoblastos deixam nela aprisionados seus prolongamentos, formando verdadeiras vias de comunicação direta da dentina com a polpa através dos túbulos dentinários, sendo esta responsável pela formação e nutrição da dentina, além da percepção de estímulos externos pelas terminações nervosas da polpa. Enquanto a vitalidade pulpar for mantida, a interação entre dentina e polpa é inquestionável $^{78}$. 


\subsubsection{Dentina}

A dentina é constituída de, aproximadamente, $65 \%$ em peso de matéria inorgânica, praticamente toda ela na forma de hidroxiapatita, $20 \%$ em matéria orgânica, composta basicamente por colágeno, $2 \%$ de proteoglicanas, glicosaminoglicanas, glicoproteínas e lipídios e 13\% de água. Em volume, essa relação altera-se para 45\% de matéria inorgânica, $33 \%$ de conteúdo orgânico e $22 \%$ de água ${ }^{57,75,78}$.

Durante a formação dentinária, especificamente, durante o processo de deposição de matriz na dentina pelos odontoblastos, estes deixam seus prolongamentos nela aprisionados, formando verdadeiras vias de comunicação direta entre dentina e polpa. Os canais onde se encontram tais prolongamentos são os também denominados túbulos dentinários que, em teoria, independente de conter ou não um prolongamento citoplasmático de um odontoblasto, representa uma célula odontoblástica ${ }^{76}$. GARBEROGLIO e BRANNSTRÖN ${ }^{26}$, 1976, demonstraram que os túbulos dentinários estão dispostos radialmente, estando seu maior diâmetro voltado à câmara pulpar. Sendo assim, à medida que se aumenta a proximidade da dentina com a polpa, maior a densidade de túbulos dentinários por área delimitada, maior o diâmetro dos túbulos e maior a permeabilidade dentinária. Esta varia ainda de acordo com a idade do dente, o grau de mineralização dos túbulos, as modificações teciduais na dentina, a localização na própria dentina, a razão entre os túbulos e a dentina intertubular e a presença de qualquer substância capaz de alterar a condutividade de fluidos através dos túbulos ${ }^{57}$. 
Apesar do seu alto grau de mineralização, a dentina é rica em matriz orgânica composta de fibras colágenas envolvidas por substância amorfa ${ }^{6}$. Essa característica estrutural da dentina traduz-se em um substrato rico em fibras colágenas, circunjacente à junção amelodentinária, ou farto em matéria inorgânica, à medida que se aproxima da polpa ${ }^{78}$.

A dentina ainda apresenta fatores de crescimento na matriz dentinária ${ }^{96}$, sendo que sua liberação no decorrer de procedimentos clínicos ou mesmo como resultado da progressão de lesões cariosas pode atuar como moléculas de sinalização no processo de reparo ${ }^{90,99}$. A identificação dessas moléculas destaca, mais uma vez, a relação íntima entre o comportamento celular da polpa e a matriz dentinária ${ }^{57}$. É possível que esses fatores sejam responsáveis por mediar as respostas pulpares a injúrias, preparos cavitários ou procedimentos restauradores ${ }^{78}$.

\subsubsection{Polpa dentária}

A polpa dentária, constituída de $75 \%$ de água e $25 \%$ de matéria orgânica, é um tecido conjuntivo frouxo com características próprias, que é ricamente vascularizado e celularizado, estando circunscrita e protegida pela dentina. Na sua região periférica, existem os odontoblastos, seguidos de uma zona praticamente acelular (basal ou acelular de WEIL), e da zona rica em células. A região central é rica em vasos sanguíneos e fibras nervosas de função sensorial (fibras mielínicas) e mecânica (fibras amielínicas) $)^{6,38,87,88,96}$. 
Embora seja um tecido formado basicamente por fibroblastos, células mesenquimais indiferenciadas, vasos sangüíneos, fibras colágenas e fibras nervosas, morfologicamente a polpa é descrita por zonas concêntricas e histologicamente distintas ${ }^{78}$.

A camada odontoblástica, a mais externa camada pulpar, é constituída pelos corpos celulares dos odontoblastos, que se encontram localizados imediatamente subjacentes à pré-dentina. Esse grupo celular é unido por junções estáveis denominadas desmossomos ${ }^{44}$, que limitam a permeabilidade da camada odontoblástica através da restrição da passagem de moléculas, íons e fluidos para a polpa ${ }^{78,98}$. Entretanto, sua função principal é a produção de dentina.

Imediatamente abaixo da camada odontoblástica, observa-se a zona acelular de Weil, rica em capilares sangüíneos, fibras nervosas amielínicas (mecâncas) e processos citoplasmáticos de fibroblastos ${ }^{78}$. Já a zona celular, é densamente povoada por fibroblastos, células mesenquimais indiferenciadas, macrófagos e linfócitos. A morte de odontoblastos leva ao aumento de mitoses na zona celular ${ }^{32}$ e migração destas células para a camada odontoblástica ${ }^{22}$ sendo este provavelmente o primeiro passo para a recomposição da camada odontoblástica após injúria pulpar. Isso só é possível devido à capacidade das células ectomesenquimais de diferenciarem-se em odontoblastos e, conseqüentemente, reativarem a capacidade reparadora da polpa em uma região afetada ${ }^{59}$.

A massa central deste tecido é composta, no entanto, pelo corpo pulpar propriamente dito, constituído de vasos sangüíneos e nervos, 
entremeados por tecido conjuntivo rico em fibroblastos e células ectomesenquimais indiferenciadas. É responsável pela percepção de estímulos externos, sejam eles térmicos, táteis, químicos, osmóticos ou de transmissão, na forma de dor ${ }^{78}$, ao sistema nervoso central.

Com relação à transmissão de estímulos, esta ocorre através de fibras sensoriais que adentram o tecido pulpar pelo forame apical ou canais acessórios e seguem, principalmente, o trajeto dos vasos sangüíneos ${ }^{57}$. A rede de fibras se ramifica em terminações nervosas na região odontoblástica, subodontoblástica e nos espaços periodontoblásticos dos túbulos dentinários ${ }^{17,23}$. Dentre as fibras sensoriais (mielínicas) da polpa, foram identificadas as fibras mielínicas A- $\delta$ e fibras $C$ amielínicas ${ }^{57,74}$. As fibras A- $\delta$ estão próximas à junção dentinopulpar, apresentando limiar de estimulação relativamente baixo, o que lhes permite captar dores lancinantes. Já as fibras nociceptivas C, encontram-se distribuídas por todo o tecido pulpar e apresentam limiar para estimulação relativamente alto, captando estímulos de dor relacionados a danos teciduais. Essas fibras captam sensações de queimação e dor menos suportável que aquelas captadas pelas fibras $A-\delta^{13}$.

Em condições normais de vitalidade, a polpa apresenta uma elevada capacidade de defesa, de cicatrização e reparo e, em virtude de suas terminações sensoriais, os estímulos aplicados sobre o complexo dentinopulpar, independente de sua natureza ou intensidade, são traduzidos como dor ${ }^{76}$. 
Vistas algumas das características entendidas como mais importantes à compreensão do mecanismo de dor que se tem nos quadros de hiperestesia dentinária, torna-se interessante abordar a origem de sua terminologia. Os termos sensibilidade ou hipersensibilidade, dental ou dentária, são freqüentemente encontrados quando queremos nos referir a ela: hiperestesia dentinária ${ }^{74,87}$.

A sensibilidade dentinária é uma resposta normal do organismo quando se tem situação em que a dentina se encontra exposta ao meio bucal. Já a hipersensibilidade dentinária pode indicar uma sensibilidade excessiva, uma situação imunológica do organismo ${ }^{97}$.

PEREIRA $^{74}$, em 1995, comenta que o termo dental é inapropriado por ser um termo demasiadamente genérico para apontar a particularidade da condição estésica da dentina.

Diante disso, para apontarmos esta condição excessiva de dor que ocorre na dentina, utilizou-se do termo hiperestesia dentinária, sugerido por PEREIRA $^{74}$, 1995, para traduzir a sensação dolorosa da dentina a um determinado estímulo, que não seja a cárie dental.

\subsection{Hiperestesia dentinária}

\subsubsection{Incidência e prevalência}

A hiperestesia dentinária é uma das condições mais desconfortáveis para os pacientes e de grande dificuldade para os dentistas. No entanto, a 
quantidade de estudos epidemiológicos sobre este assunto ainda é escassa $^{80}$.

Estudos ainda demonstram que a hiperestesia dentinária afeta entre $10 \%$ a $20 \%$ da população, sendo a prevalência similar em várias partes do mundo. Pode acometer qualquer dente, porém é mais comum em caninos e pré-molares, ocorrendo quase que invariavelmente na face vestibular ${ }^{4,16,62,91}$. Verificam também, clinicamente, semelhante predisposição à hiperestesia dentinária entre os $\operatorname{sexos}^{4,15,91}$ e ainda alta prevalência em pacientes tratados periodontalmente ${ }^{87}$.

BISSADA $^{9}, 1994$, relata em seu trabalho que a hiperestesia dentinária é mais comumente encontrada em indivíduos jovens que tenha área radicular exposta, apesar de ser comum esta ocorrência em indivíduos mais velhos. Segundo o autor, tal fato pode ser atribuído aos seguintes fatores: (1) com a idade, os túbulos dentinários são preenchidos por minerais, o que reduz a movimentação do fluido no seu interior; (2) redução evidente do número de túbulos; (3) redução do tamanho da câmara pulpar devido ao aumento da incidência de dentina reparadora; (4) diminuição do número de células, da vascularização bem como da quantidade de fibras nervosas na cavidade pulpar.

Os dentes mais acometidos seriam caninos e pré molares, região cervical vestibular ${ }^{2,9}$ 


\subsubsection{Etiologia}

Com relação à etiologia da hiperestesia dentinária, é importante que se saliente que a dentina, em condições normais, quando ainda recoberta pelo esmalte na região correspondente à coroa dentária e pelo cemento, na porção radicular, não é hiperestésica. A dentina começa a acusar algum grau de hiperestesia a partir do momento que é exposta ao meio bucal. Esta, a exposição dentinária, geralmente apresenta como causa o desgaste de suas estruturas de proteção (esmalte e cemento, já citados), sendo importante ressaltar que, em aproximadamente $10 \%$ dos indivíduos, na região que corresponde à junção amelocementária, não há, na realidade, a união de esmalte e cemento (gaps), o que leva à exposição de dentina nesta área, sendo que esta pode ou não apresentar-se hiperestésica ${ }^{100}$.

Outra situação que pode levar à exposição de dentina e, conseqüentemente, à presença de área hiperestésica, é a perda de estrutura dentária por lesões não cariosas: erosão, abrasão, atrição, abfração assim como pela associação destes fatores. A abrasão pode ser entendida como a perda de substância dentária por ação mecânica, como o que se tem quando na escovação inapropriada dos dentes ${ }^{19}$. A erosão ocorre quando há perda de estrutura dentária em conseqüência a um processo químico ou idiopático, com ausência bacteriana ${ }^{80,87}$. Já a atrição, esta pode ser entendida como o desgaste fisiológico ou não das superfícies dentárias pela ação da mastigação - há contato dente / dente ${ }^{27,74,95}$. A abfração pode ser definida como a perda patológica de tecido duro de uma região do dente distante da atingida por forças biomecânicas. Portanto, tem-se que a 
hiperestesia dentinária é considerada uma ocorrência clínica de origem multifatorial $^{74}$.

A erosão química é uma outra situação que pode igualmente levar à ocorrência da hiperestesia dentinária. Ela explica como vários tipos de ácidos (de origem exógena), presentes em alimentos, drogas e bebidas podem descalcificar o esmalte e, dessa forma, ocasionar a hiperestesia pela exposição de dentina ao meio bucal ${ }^{33,47}$. A regurgitação, que pode estar associada a doenças gastrointestinais ou de origem psicosomática, pode contribuir à exacerbação das lesões pela ação de ácidos, agora, de origem endógena ${ }^{4,5,47,92,101}$. Importante mencionar que as lesões resultantes da ação de substâncias ácidas apresentam o aspecto de pires, tendo por característica a presença de bordas indefinidas. Em pacientes acometidos por doenças como bulimia e/ou anorexia, a verifica-se a presença dessas lesões principalmente na superfície lingual dos incisivos superiores, deixando-as planas, lisas e sem brilho. Em ambas as situações, a acidez constante da cavidade bucal em virtude dos vômitos e regurgitações, associada à xerostomia e diminuição da capacidade tampão da saliva levam à dissolução das estruturas mineralizadas dos dentes ${ }^{92}$. A este fenômeno denomina-se perimólise, sendo importante salientar que é alta a incidência de hiperestesia em dentes erosionados ${ }^{19}$.

Temos ainda que o desgaste abrasivo das estruturas de proteção dos dentes, como o que ocorre quando na escovação inadequada dos mesmos, pode também levar à exposição dentinária e, conseqüentemente, aos sintomas de hiperestesia. A grande preocupação, nesse contexto, seria com 
o tamanho e a dureza das partículas dos dentifrícios bem como pressão exercida durante o processo de escovação, qualidade da escova utilizada e freqüência ${ }^{87}$. As lesões originadas pela pelo desgaste por abrasão surgem, mais freqüentemente, em dentes superiores anteriores e nas áreas de prémolares ${ }^{85}$. Com relação à aparência dessas lesões, geralmente apresentam aspecto de cunha, sendo que a dentina exposta apresenta-se altamente polida, lisa e dura e, o tecido gengival adjacente, características de normalidade e boa higiene. Alguns pesquisadores já têm correlacionado a melhor higiene oral ao maior grau de acometimento de hiperestesia $20,48,51$. Um outro fator também apontado por estudos como promotor de abrasão seria o tratamento periodontal, seja ele cirúrgico ou mecânico, o que igualmente viabiliza a ocorrência de hiperestesia dentinária ${ }^{2}$. Importante mencionar que a ocorrência de hiperestesia em presença de lesões por abrasão é quatro vezes maior que a registrada frente a lesões por erosão ${ }^{86}$.

A abfração, também relatada como uma das possíveis causas para lesões cervicais não cariosas, sugere uma possível influência etiológica do traumatismo oclusal sobre os dentes, durante a mastigação. Segundo esta teoria, forças excêntricas sobre os dentes podem resultar em tensões de tração, ou seja, há deflexão da estrutura dental, produzindo a ruptura do esmalte na região cervical dos elementos dentários, o que facilita a ação de ácidos e abrasivos durante a escovação. Tais lesões possuem por característica a ocorrência de maneira isolada, com margem bem definida e com característica de profundidade ${ }^{46}$. 
A polpa apresenta grande potencial de resposta dolorosa mesmo em situações em que o estímulo é aplicado à distância, como nas camadas mais superficiais da dentina. A maneira como ocorre a transmissão do estímulo através da dentina, desde suas camadas mais superficiais está, ainda, pouco esclarecida ${ }^{76}$. Existem, porém, várias teorias que buscam explicar tal fenômeno ${ }^{29,40,42,43,76}$, sendo que, atualmente, a mais aceita para a compreensão do mecanismo de ativação nervosa associada à sensibilidade da dentina é da natureza hidrodinâmica ${ }^{11}$, que baseia-se na hipótese da dentina sensível ser permeável em toda sua extensão ${ }^{65}$. Entretanto, para uma melhor comprensão das teorias propostas que tentam explicar o mecanismo da hiperestesia dentinária, faz-se necessário compreender a natureza e as características do complexo dentinopulpar ${ }^{80}$.

Do ponto de vista fisiológico, o complexo dentinopulpar sofre alterações freqüentes em sua microestrutura, resultante da função dentária, do desgaste gradativo do esmalte e da decorrência de lesões dentárias de natureza não cariosa e idiopática ${ }^{94}$.

A polpa, por sua vez, é um tecido conjuntivo frouxo, ricamente celularizado e vascularizado, com uma intensa distribuição de fibras nervosas, de função sensorial (fibras mielínicas) e mecânica (fibras amielínicas) $6,38,88,96$. As terminações sensitivas são predominantes, dividindo-se em visceral e parietal, sendo a visceral aquela encontrada no centro da polpa, cujas fibras mielínicas formam o plexo de Mamery. Fazem parte deste plexo as fibras $\mathrm{C}$, que são as últimas a serem ativadas, isso devido à sua localização central e à baixa velocidade de condução dos 
impulsos nervosos. No entanto, é válido ressaltar que, dependendo da gravidade do agente agressor, sua ativação pode ser imediata. Assim que as fibras mielínicas encaminham-se para a camada odontoblástica (periferia), perdem sua bainha de mielina, originando o plexo de Raschkov, que é constituído de fibras amielínicas, fazendo parte do mesmo, as fibras $A$, cuja velocidade de condução dos impulsos nervosos é alta, o que da transmissão do impulso nervoso uma condição quase que imediata à aplicação do estímulo $^{21,80}$.

A particularidade das terminações nervosas sensoriais da polpa faz com que todos os estímulos aplicados sobre o complexo dentinopulpar, independente de sua natureza ou intensidade, sejam traduzidos como dor. De modo geral, as terminações nervosas inexistem na maior parte da dentina e, quando presentes, estendem-se a não mais que $0,1 \mathrm{~mm}$ no interior dos túbulos dentinários em regiões de polpa intacta ${ }^{76}$.

$\mathrm{Na}$ tentativa de se explicar o mecanismo da hiperestesia dentinária, como visto, várias teorias foram elaboradas, embora nenhuma delas leve à perfeita compreensão de como um estímulo na superfície de uma dentina hiperestésica possa provocar dor.

- TEORIA DA TRANSDUÇÃO - segundo esta teoria, existe um arranjo sináptico entre terminações nervosas sensoriais e processos odontoblásticos $^{74,88}$. Entretanto, nenhuma substância neurotransmissora foi detectada nesta região ${ }^{74}$.

- TEORIA DA MODULAÇÃO - corresponde à teoria de que, frente a um estímulo, os odontoblastos liberariam substância 
neurotransmissora, proteínas vasoativas estimuladoras da dor e aminoácidos, o que modularia a ação potencial das fibras nervosas ${ }^{74}$.

- "GATE CONTROL" E TEORIA DA VIBRAÇÃO - Segundo essa teoria, as chamadas fibras $\mathrm{C}$, sofrem mudanças de potencial diante de determinados estímulos, ampliando a percepção à dor - "pain-gates" -, o que exacerbaria a passagem dos estímulos sensoriais ${ }^{74,80,88}$. Esta teoria não consegue explicar, no entanto, o mecanismo através do qual os estímulos são transmitidos e identificados pelas terminações nervosas pulpares.

- teORIA DA HIDRODINÂMICA - baseia-se nos estudos de BRÄNNSTRÖM ${ }^{10}$, primeiramente, e mais tarde de GARBEROGLIO e BRÄNNSTRÖM ${ }^{26}$, que sustentam o fato de que, apresentando a dentina túbulos com paredes relativamente rígidas contendo material fluido ou semi-fluido, alteração da hidrodinâmica dos fluidos no interior dos túbulos, nas regiões em que se tem dentina exposta, poderia causar sensibilidade, visto que, frente a um estímulo, este material se movimenta através da estrutura dentinária, transmitindo-o, desta maneira, à polpa ${ }^{10,26,74}$. A conformação cônica dos túbulos dentinários, associada ao movimento de fluidos por atração capilar, em teoria, obedece às mesmas leis físicas do deslocamento de líquidos em capilares de vidro, a qual considera que o rápido movimento dos fluidos (2 a $4 \mathrm{~mm}$ por segundo) ativa os nervos mecano-receptores $A \beta$ e $A \delta$ do tecido pulpar, responsáveis pela transmissão da dor ${ }^{76}$. Por ser assim, a estimulação das terminações 
nervosas próximas das camadas odontoblásticas seria provocada pela variação da pressão intrapulpar decorrente da movimentação do fluido dentinário em direção à polpa ou sentido contrário, dependendo da natureza do estímulo ${ }^{74}$.

Ainda com relação à teoria da hidrodinâmica, a mais aceita atualmente para explicar o mecanismo da hiperestesia dentinária, tem-se que, em 1981, GREENHILL \& PASHLEY ${ }^{34}$ propuseram avaliar o efeito de agentes dessensibilizantes utilizados na clínica na redução do índice do fluxo de fluido através da dentina in vitro. Para tanto, discos de dentina preparados a partir de terceiros molares humanos extraídos foram tratados com ácido cítrico a $50 \%$ para remover os debris dos orifícios tubulares. Assim, após posicioná-los no dispositivo para mensuração da condutividade hidráulica, o índice de fitração da solução tamponada através da dentina sob pressão de $240 \mathrm{~cm} \mathrm{/} \mathrm{H}_{2} \mathrm{O}$ foi medido. O lado oclusal dos discos foi tratado com um agente dessensibilizante para verificar a redução do índice do fluxo de fluido. Os discos com mais de $50 \%$ de redução no índice de fluxo foram então examinados no microscópio eletrônico de varredura para determinar se os agentes que reduziram o índice do fluxo também ocluíram parcialmente os orifícios tubulares. Estes modelos in vitro proporcionaram um método quantitativo útil para selecionar muitas preparações que foram utilizadas no passado para diminuir a sensibilidade dentinária.

A movimentação do fluido nos túbulos dentinários ocorre quando estímulos atuam sobre a dentina exposta pela remoção de cemento ou esmalte. Dentre estes estímulos pode-se citar o tato, as soluções osmóticas, 
mudanças de temperatura e jatos de ar. No estímulo tátil, no momento em que o clínico faz uso de uma sonda exploradora $n^{\circ} 5$, por exemplo, a pressão exercida sobre a superfície dentinária causa deslocamento interno de seu conteúdo fluido, ativando os mecanoceptores pulpares. Ao se retirar a pressão, recorre o equilíbrio hidrodinâmico da dentina, aliviando a sensibilidade. Pacientes mais sensíveis tendem a sentir dor em pequena intensidade Com relação ao estímulo osmótico, a colocação sobre a superfície da dentina uma solução com concentração diferente da do fluido dentinário faz com que o soluto saia da solução mais concentrada (maior pressão osmótica) para a menos concentrada, originando movimentação do fluido dentinário e, dessa forma, ativando os mecanoceptores pulpares e induzindo à dor. Já o estímulo térmico, este pode ser através do calor ou frio, sendo que o primeiro causa a dilatação do fluido e o segundo, a sua contração, ambos ativado os mecanoceptores pulpares. E ainda temos que, clinicamente, aplicado pelo jato de ar, o estímulo evaporativo também causa a movimentação do fluido em ambos os sentidos, dependendo da direção e intensidade dos jatos de ar, modificando sua normalidade e ativando também os mecanoceptores ${ }^{76,80}$.

A presença de smear layer e smear plugs é ainda um outro fator que regula a condutividade hidráulica da dentina $e$, conseqüentemente, a hiperestesia. A presença das mesmas pode amenizar a sensibilidade dentinária, permitindo que se tenha uma superfície menos suscetível à dor. Por ser assim, na dentina hiperestésica geralmente não há smear layer, e os túbulos dentinários encontram-se expostos. 
PASHLEY ${ }^{64}$, em 1986, em seus estudos, mostrou que, onde há túbulos dentinários abertos, há maior sensibilidade devido ao movimento de fluidos mais intenso.

Ainda com relação ao movimento do fluido através dos túbulos dentinários, normalmente, há também um fluxo externo de fluido através da dentina exposta e existem evidências de que este fluxo é um fator significante na taxa com que as substâncias químicas se difundem através da dentina ${ }^{52}$. A taxa do fluxo de fluidos através da dentina é dependente de vários fatores como a pressão do fluido tissular da polpa que, por sua vez, depende, em parte, da microvascularização da polpa ${ }^{52}$.

Desse modo, pode-se adiantar que qualquer situação e/ou substância que altere a permeabilidade dos túbulos dentinários bem como o fluxo do fluido neles existentes pode levar ao aparecimento da hiperestesia dentinária.

\subsubsection{Diagnóstico}

O adequado diagnóstico é algo essencial para o tratamento efetivo de qualquer enfermidade. Apesar da hiperestesia dentinária não ser considerada doença, também deve ser corretamente diagnosticada visto que apresenta sintomas que podem confundi-la com outras doenças comum ao meio bucal. Por ser assim, mais uma vez, faz-se importante realização da anamnese, que deve ser acompanhada do exame clínico minucioso do paciente, exames complementares como o radiográfico para se chegar ao correto diagnóstico e, conseqüentemente, tratamento efetivo da mesma ${ }^{74}$. 
Segundo PEREIRA ${ }^{74}$, 1995, o paciente que apresenta hiperestesia dentinária apresenta, geralmente, os seguintes aspectos:

- dor provocada por estímulos térmicos (alimentos frios e/ou quentes, ar durante a conversação ou mesmo aspiração), químicos (alimentos doces e ácidos) e táteis (escovação e sondagem);

- dor localizada, com definição do dente e região envolvidos;

- dor aguda, de curta duração e que cesse após a remoção do estímulo;

- períodos de remissão espontânea, que muitas vezes podem coincidir com o estado de ansiedade do paciente.

Segundo ainda este mesmo autor, os sinais e sintomas apresentados em situações em que se trata da hiperestesia dentinária tem grande semelhança com os apresentados na pulpite reversível ou mesmo em exposições dentinárias não enquadradas no grupo de lesões cervicais não cariosas.

Alguns autores ${ }^{18,97}$ relatam determinadas situações clínicas que podem ser facilmente confundidas com a hiperestesia dentinária, dificultando o adequado diagnóstico como: perda de estrutura dentária devido à fratura, trincas da coroa dentária, presença de cárie, sensibilidade pós-operatória, dentes com contados exagerados, que estão em hiperfunção. A análise dessas situações clínicas mostra que o sintoma comum entre elas é a ocorrência de dor provocada pelos mesmos agentes que estimulam a hiperestesia dentinária. Com exceção da dor provocada pela hiperfunção, todos os eventos aqui mencionados estão relacionados com algum grau de 
exposição dentinária, mas apresentam etiologias diferentes e variam em freqüência e severidade. É importante compreender ainda que mecanismo da dor relatado para a hiperestesia dentinária não tem, necessariamente, relação com a ocorrência de fenômenos patológicos da polpa. Representa, em grande parte das vezes, dor de origem dentinária, resultante de estímulos superficiais, exacerbando os mecanismos fisiológicos do complexo dentinopulpar ${ }^{76}$. Salienta-se, mais uma vez, que, nas situações de hiperestesia dentinária, tem-se dor aguda, de curta duração e que desaparece coma remoção do estímulo ${ }^{74,76}$.

\subsection{Oclusão dos túbulos dentinários e hiperestesia dentinária}

A dentina, como já mencionado, apresenta túbulos dentinários por onde permeia uma substância fluida sendo sua movimentação tida hoje como a principal responsável pelo desencadear do mecanismo da dor nos casos de hiperestesia dentinária.

A smear layer, camada de formada por pequenas partículas amorfas de dentina, minerais e matriz orgânica, que se deposita sobre a embocadura dos túbulos dentinários após o corte da superfície de dentina, possibilita grande redução da permeabilidade dentinária ${ }^{70}$, visto que, de certa forma, possibilita a oclusão parcial dos túbulos dentinários, o que reduz o fluxo de fluido e, conseqüentemente, a sensibilidade dentinária a estímulos nela aplicados $^{3,12}$. A presença de smear layer e smear plugs é mencionada como um fator que regula a condutividade hidráulica da dentina e, conseqüentemente, a ocorrência da hiperestesia, já que sua presença pode 
amenisar a sensibilidade dentinária, permitindo que se tenha uma superfície menos suscetível à dor. Por ser assim, na dentina hiperestésica geralmente há ausência de smear layer e os túbulos dentinários encontram-se expostos $^{80}$. Nesse sentido, BRÄNNSTRÖN; JOHNSON ${ }^{12}$, 1974, relatam que a remoção da smear layer aumenta a hipersensibilidade dentinária.

PASHLEY; MICHELIN; KEHL ${ }^{72}$, em 1981, examinaram em microscópio eletrônica de transmissão, a aparência da dentina antes e após da remoção de sucessivas camadas da smear layer tratadas com ácido cítrico $6 \%$ e relacionaram estes efeitos com a permeabilidade dentinária in vitro. Após observação em microscópio eletrônico de transmissão, concluíram que o uso do ácido cítrico a $6 \%$, durante pequenos intervalos de tempo, permite a remoção seqüencial da smear layer da dentina humana. Observaram também que a permeabilidade dentinária aumenta rapidamente com o condicionamento ácido, expondo as embocaduras dos túbulos em apenas 5 segundos, alcançando o valor máximo após 15 segundos de condicionamento.

Num outro estudo, em 1985, PASHLEY e GALLOWAY ${ }^{69}$ avaliaram a smear layer através de microscopia eletrônica de varredura e por meio de medições de condutividade hidráulica antes e depois de 2 minutos da aplicação tópica de cloreto de potássio, oxalato de potássio neutro, ácido oxálico ou ambos oxalatos neutro e ácido. A smear layer tratada foi então reavaliada microscopicamente e funcionalmente antes e depois do desafio ácido. A smear layer, quando tratada com cloreto de potássio, não sofreu alteração microscópica nem funcional e foram suscetíveis ao 
condicionamento ácido. Já as superfícies dentinárias tratadas com qualquer das soluções de oxalato tornaram -se menos permeáveis e ácido resistentes. O estudo vem a confirmar a necessidade da oclusão dos túbulos dentinários para sua menor permeabilidade.

Com relação aos efeitos produzidos por substâncias à base de oxalato de potássio na permeabilidade dentinária, em 1990, PEREIRA et al. ${ }^{79}$ estudaram o efeito do oxalato de potássio a $3 \%, \mathrm{pH} 6$, em pacientes com hiperestesia dentinária na região cervical em comparação a outras técnicas anti-hiperestésicas, entre elas, a brunidura da dentina, o emprego de adesivo dentinário (Scotchbond - 3M) e fluorfosfato acidulado. Observouse que, após o tratamento dos 200 dentes coletados para a amostra, os padrões de hiperestesia foram bastante reduzidos após o tratamento da dentina com os diferentes métodos empregados. Todos os dentes tratados com o oxalato de potássio apresentaram padrões de hiperestesia de zero a um, isto é, ausência de hiperestesia e hiperestesia mínima, após 4 aplicações, por um período de 4 meses. Os resultados podem sugerir a relação existente entre a permeabilidade dentinária com a hiperestesia.

As mudanças estruturais dos túbulos dentinários em espécimes obtidos de área sensíveis ou não em dentes com sensibilidade dentinária, foram estudadas por YOSHIYAMA, M., et al., em 1989. Os autores descrevem uma nova técnica para obtenção de biópsia de dentina hipersensível, usando uma ponta diamantada cilíndrica oca. Vinte e dois pares de biópsias dentinárias foram divididos em dois grupos. Um grupo foi preparado para M.E.V. e o outro para radiomicrografias. Pequenas áreas de 
dentina hipersensíveis foram diagnosticadas clinicamente por meio de sondagem da dentina exposta. A microscopia eletrônica de varredura mostrou que muitos túbulos dentinários nas áreas hipersensíveis estavam abertos e estruturas membranosas apareceram em suas paredes internas. Nas áreas naturalmente não sensíveis da mesma superfície dentinária, a maioria dos túbulos dentinários estavam obstruídos com cristais romboédricos de todos os tamanhos. Estruturas membranosas não foram observadas nesses túbulos. Esses resultados mostraram que a hipersensibilidade dentinária ocorre quando a maioria dos túbulos encontrase abertos. Em 1990, YOSHIYAMA et al. ${ }^{102}$, estudaram, através de microscopia eletrônica de transmissão e micro-análise radiográfica, a ultraestrutura das embocaduras dos túbulos dentinários nas camadas superficiais de espécimes de dentina obtidos com uma técnica de biópsia a partir de áreas hipersensíveis e naturalmente dessensibilizadas de superfícies radiculares expostas in vivo. As imagens de microscopia eletrônica de transmissão mostraram claramente que as embocaduras da maior parte dos túbulos estavam ocluídas com cristais minerais em áreas naturalmente dessensibilizadas sendo que, nas áreas hiperestésicas, encontravam-se vazias e circundadas por dentina peri e inter-tubular.

Novamente com relação à smear layer, ADDY et al. ${ }^{1}$, em 1987 , através da microscopia eletrônica de varredura, demonstraram que a dentina exposta durante 5 minutos a líquidos como vinho tinto e branco, sucos de frutas cítricas, suco de maçã e iogurte tinha a smear layer removida, o que promovia a abertura de grande número de túbulos dentinários, o que 
demonstra a suposta ação de tais substâncias no desencadeamento da hiperestesia dentinária. Ainda neste contexto, o estudo realizado por PASHLEY, D.H.; GALLOWAY, S.E., 1985, mostrou que mesmo quando expomos a dentina a substâncias ácidas a tempos pequenos como 10 segundos, ainda que a smear layer esteja presente, a fase mineral é dissolvida, levando ao aumento da permeabilidade dentinária e, conseqüentemente, aos efeitos irritantes de produtos microbianos à polpa.

As evidências confirmam, portanto, o que PASHLEY ${ }^{65}$, em 1992, comentou em seu estudo: que a teoria hidrodinâmica está baseada na premissa de que a dentina sensível é permeável ao longo dos túbulos. Se o mecanismo de transmissão de estímulos através da dentina envolve o movimento de fluidos, a hipersensibilidade dentinária está diretamente relacionada à dimensão, número e grau de abertura dos túbulos dentinários 77. Por ser assim, fica confirmada a necessidade do conhecimento dos fatores que podem levar à maior permeabilidade dentinária para se obter êxito na prevenção e tratamento da hiperestesia dentinária, uma das condições mais desconfortáveis para os pacientes.

\subsection{Erosão dentária e a ingestão de bebidas de teor ácido}

A erosão pode ser definida como a perda irreversível de estrutura dentária induzida por ácidos sem haver, no entanto, envolvimento bacteriano 14,20,25,47,48,51,85,89. Sua etiologia é multifatorial e várias interações complexas estão envolvidas quando na ocorrência de todo o processo erosivo ${ }^{1,47}$ sendo, portanto, ainda pouco compreendida nos dias atuais. 
Para que ocorra a erosão, há necessidade do contato de substâncias químicas ácidas com o meio bucal visto a necessidade do esmalte dentário sofrer descalcificação e, desse modo, sofrer os efeitos do processo erosivo nele iniciado. Como fontes de ácidos, temos as extrínsecas e as intrínsecas. As fontes extrínsecas correspondem às comidas e bebidas de teor ácido, medicamentos ingeridos bem como os ácidos presentes no meio ambiente ${ }^{8,51}$ e todos os tipos de comidas ácidas com baixa concentração de cálcio e fosfato ${ }^{48}$. Os ácidos de origem intrínseca são os gástricos, que entram em contato com os dentes durante desordens gástricas que geram regurgitação, refluxo e em casos de bulimia ${ }^{51}$.

A influência dos constituintes da dieta como possíveis causadores da erosão dentária foi reconhecida já na década de 40 e 50, quando estudos a respeito da erosão buscaram relacioná-la ao consumo de sucos de fruta 39,93. Alguns trabalhos têm ainda demonstrado que o consumo de bebidas que contêm substâncias ácidas pode ter alguma influência na ocorrência da erosão dentária ${ }^{45,47,51,58}$, embora existam alguns poucos estudos ${ }^{56}$ que relatam não poder correlacionar o hábito de ingestão de algumas bebidas contendo componente ácido à ocorrência da erosão dentária, visto sua etiologia multifatorial.

Na busca de uma resposta com relação a esta complexa etiologia, em 1973, McDONALD e STOOKEY ${ }^{54}$ determinaram, in vitro, a capacidade de várias marcas de refrescos em causar dissolução do esmalte dental bem como a influência in vivo da adição de fosfatos a esses produtos. Os autores dividiram a pesquisa em duas etapas sendo que, na primeira foram 
utilizados dentes bovinos extraídos, divididos em grupos e expostos a produtos comercias com e sem a adição de compostos fosfatados; na segunda etapa, os mesmos produtos foram adicionados à dieta de ratos. Todos os produtos testados foram capazes de provocar dissolução no esmalte, em ambas as partes do estudo, não estando relacionada a adição do fosfato aos produtos ao seu menor potencial erosivo. RUGG-GUNN et al. $^{84}, 1998$, avaliaram a possível diminuição do potencial erosivo de algumas bebidas ácidas (água destilada, suco de laranja artificial com e sem adição de cálcio e "cola" diet) pela adição de componente à base de cálcio (calciumcitrate-malate - CCM), que é uma combinação de sais de cálcio (carbonato de cálcio) e ácido cítrico e málico. Porém, de acordo com este estudo, não houve tal correlação, não podendo tal substância alcalina ser considerada efetiva na diminuição do potencial ácido das substâncias ácidas avaliadas. Em contradição, LARSEN e NYVAD ${ }^{45}, 1999$, avaliaram a erosão do esmalte causada por refrigerantes e suco de laranja que continha ou não adição de cálcio e fosfato em sua composição e encontraram que estes últimos causavam lesão de erosão mais profunda em esmalte quando comparada àquela produzida pelo suco contendo os dois íons em grandes quantidades, conferindo ao suco de laranja um alto efeito preventivo à erosão.

CAIRNS et al. ${ }^{14}$, em 2002, ainda estudando a ação de sucos no processo de erosão dentária, mostraram que aqueles que necessitam ser diluídos anteriormente ao consumo podem, assim como os naturais e/ou sucos prontos, ter influência no desgaste dentário por abrasão. Ficou demonstrado que enquanto a diluição do suco tem pouco efeito nos valores 
de $\mathrm{pH}$, quanto mais diluído estiver o suco, menores os valores da acidez titulável. Sendo assim, concluíram que os sucos diluídos apresentam potencial erosivo, que pode ser diminuído substancialmente pelo acréscimo de água.

A ingestão de bebidas de teor ácido como as bebida do tipo "cola" tem sido associada à ocorrência de erosão ${ }^{25,85}$. A maneira como são ingeridas corresponde ainda a mais um fator que pode ter influência direta nas possíveis causas da mesma. O uso de canudos, por exemplo, para a ingestão destas bebidas parece ser um método menos prejudicial para a ingestão de bebidas ácidas e açucaradas, podendo ser inclusive recomendada na tentativa de se minimizar os efeitos das mesmas com relação ao desgaste das estruturas dentárias ${ }^{36}$.

A Coca Cola, especificamente, foi uma bebida estudada em 2002 por ROOS e DONLY ${ }^{83}$ provavelmente devido ao seu grande consumo na atualidade. Os autores pesquisaram a variação que se tem do $\mathrm{pH}$ da placa dental in vivo após a ingestão de Coca Cola nas formas regular e diet. Concluíram, pois, que o consumo da Coca Cola regular causou maior diminuição do $\mathrm{pH}$ da placa dentária quando comparada à Coca Cola diet. Porém, para ambas, os valores do mesmo não alcançaram o do $\mathrm{pH}$ crítico, necessário à desmineralização e dissolução do esmalte.

As bebidas ingeridas como suplementos antes ou após a atividade física têm sido igualmente relacionadas a perda de estrutura dentária por processo químico. MILOSEVIC, et al. ${ }^{56}, 1997$, avaliou a incidência de lesões erosão num grupo de nadadores e ciclistas que, em algum tempo, 
consumiam tais bebidas. Como os dados obtidos para este estudo foram oriundos de questionários preenchidos pelos próprios participantes da amostra estudas bem como pelo fato de conter perguntas abrangentes como hábitos de higiene oral, outros hábitos alimentares, entre outras, não foi possível determinar, entretanto, a relação entre o consumo das bebidas avaliadas com a presença de lesões de erosão. Porém, apesar da falta de associação entre o desgaste dentário por erosão e o consumo de tais bebidas neste grupo específico de nadadores e ciclistas, uma possível associação não pode ser descartada desde que o potencial erosivo destas substancias é algo real, merecendo a atenção do cirurgião-dentista no momento da anamnese de seus pacientes com tal enfermidade. MATHEW et al., $2002^{51}$, em estudo similar, também relataram que vários atletas que faziam parte da amostra deste estudo e tinham por hábito o alto consumo de destas bebidas utilizadas como complementos antes ou após a atividade física não revelaram qualquer evidência de erosão dental e, dessa forma, concluíram que mais estudos são necessários quanto à etiologia desta enfermidade, visto ser complexa e multifatorial.

A higiene oral pode também estar associada à erosão dentária, que é freqüentemente associada a pessoas que têm um alto padrão de higiene oral. Nesse contexto, se esmalte e dentina sofrem desmineralização devido ao ataque ácido de qualquer fonte (extrínseca ou intrínseca) e, logo em seguida, procede-se com a escovação dos dentes, uma maior quantidade de tecido dental será removida. Da mesma forma, o consumo de bebidas à base de frutas à noite, previamente à escovação de antes de dormir, é algo 
que pode igualmente levar à desmineralização dos dentes ${ }^{89}$. Ainda com relação à associação da higiene oral com a ocorrência de lesões de erosão, temos o fato de alguns colutórios bucais apresentarem-se ácidos, sendo seu uso em excesso prejudicial ${ }^{7,89}$.

Como citamos anteriormente, vários são os fatores que podem estar associados à ocorrência da erosão. Ainda dentre os extrínsecos, temos que o consumo de alguns medicamentos durante um espaço tempo relativamente grande pode também ser associado ao processo erosivo. Complementos à base de íons de ferro, ácidos usados para dissolver cálculo renal ${ }^{60} \mathrm{e}$ inclusive os tabletes efervescentes de vitamina $C^{48,60}$ podem ser citados neste contexto. Em adição, medicamentos que causam diminuição do fluxo salivar como os tranqüilizantes, anti-Parkisonianos, entre outros, podem também estar relacionados à ocorrência da erosão dentária ${ }^{48}$.

A taxa de fluxo salivar ${ }^{48,105}$, como acabamos de abordar, bem como hábitos de higiene oral, já citados, podem interferir igualmente na etiologia multifatorial que apresentam estas lesões.

É importante mencionar e compreender que, nas lesões de erosão, a quantidade de mineral dissolvida ou retirada do esmalte vai depender de algumas condições como o pH da substância causadora da mesma, seu efeito tampão ou concentração de ácidos e o tempo de exposição do esmalte à substância em questão ${ }^{45}$.

Hoje, acredita-se que a prevalência da erosão dentária esteja aumentando 45,51 , presumidamente em conseqüência ao aumento do consumo destes refrigerantes, bebidas consumidas após esportes e sucos 
de frutas cítricas, o que torna necessária a melhor compreensão bem como tratamento desta entidade.

\subsection{Ingestão de bebidas de teor ácido, permeabilidade dentinária e a hiperestesia da dentina}

A hiperestesia dentinária pode ser favorecida pelo consumo de substâncias ácidas que, como relatamos, podem ter grande potencial erosivo e, desta forma, ter efeito na permeabilidade dentinária. Já se foi demonstrado que substâncias ácidas podem remover a smear layer e abrir os túbulos dentinários ${ }^{65,69}$.

MERCHANT et al., ${ }^{55}$ em 1977, compararam o grau de permeabilidade dentinária ao iodo através de difusão e filtração. Previamente ao condicionamento ácido, o grau de permeabilidade relativa ao iodo por filtração era o dobro dos valores obtidos por difusão. Após o condicionamento ácido, entretanto, a filtração produziu um aumento de 32 vezes em permeabilidade, fato que nos permitiu concluir que o condicionamento ácido, que remove os debris oclusores, permite maiores valores para a filtração em relação à difusão. PASHLEY et al. $^{72}$, em 1981 , como citado anteriormente, concluíram que o uso do ácido cítrico a $6 \%$, durante pequenos intervalos de tempo, permite a remoção seqüencial da smear layer da dentina humana. Observaram ainda que a permeabilidade dentinária aumenta rapidamente com o condicionamento ácido, expondo as embocaduras dos túbulos em apenas 5 segundos, alcançando o valor máximo após 15 segundos de condicionamento. 
Entretanto, apesar de alguns trabalhos evidenciarem a ação de substâncias ácidas na permeabilidade dentinária, são poucas as informações sobre seus efeitos sob forma de alimentos, bebidas, como se tem para a erosão, na permeabilidade da dentina e provável desencadeamento da hiperestesia ${ }^{81,82}$, sendo necessários mais estudos a respeito. 
3- PROPOSIÇÃO 


\section{3- PROPOSIÇÃO}

Este trabalho tem como objetivo geral verificar, através de teste de condutividade hidráulica in vitro, o efeito de refrigerantes e sucos de teor ácido na permeabilidade da dentina recoberta com smear layer, aplicados por dois diferentes tempos experimentais.

Considera as seguintes hipóteses nulas:

1) as bebidas de teor ácido estudadas não alteram a condutividade hidráulica dentinária;

2) a condutividade hidráulica da dentina é a mesma após os tempos experimentais propostos. 
4- MATERIAL E MÉTODOS 


\section{4- MATERIAL E MÉTODOS}

\subsection{Seleção dos dentes e obtenção dos espécimes}

Foram selecionados 60 terceiros molares humanos hígidos não irrompidos, extraídos de pacientes jovens e armazenados em solução de Timol a 0,1\% (Merck, Darmstadt, Germany) em água deionizada, a aproximadamente $4^{\circ} \mathrm{C}$.

Previamente à extração dos dentes, cada paciente preencheu o termo de consentimento esclarecido (anexos 1 e 2), conforme determinado pelo Comitê de Ética em Pesquisa da Faculdade de Odontologia de Bauru, e aprovado em reunião realizada no dia 27 de novembro de 2002.

Com relação ao tempo decorrido desde a extração dos dentes à obtenção do espécime e realização dos testes, este foi, no máximo, de 30 dias para a melhor conservação dos mesmos e padronização dos testes. Os dentes extraídos, devidamente limpos, foram fixados com cera pegajosa, aplicada na superfície oclusal da coroa em uma base de resina (Resina T208, Redifibra Comércio de Produtos para Fiberglass Ltda, São Paulo, Brasil) (Figura 1) e acoplados na matriz metálica da máquina de corte da ISOMET (Extec Corporation, Labcut 1010, USA). 


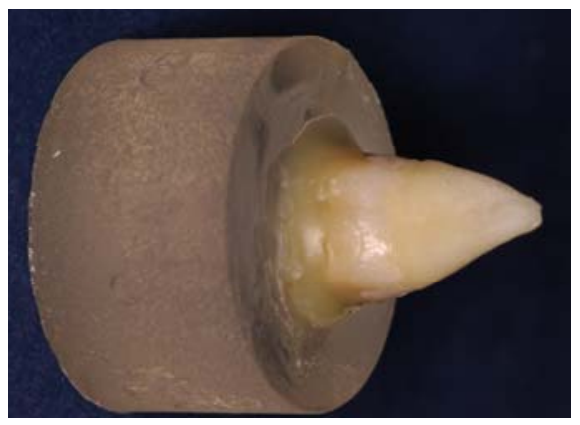

FIGURA 1 - Dente extraído, fixado à base de resina com cera pegajosa.

As raízes foram removidas através de um corte realizado ligeiramente acima da junção amelocementária e paralelamente à face oclusal, a uma altura correspondente ao teto da câmara pulpar (Figura 2). Uma segunda secção, paralela à primeira, removeu o esmalte oclusal, permitindo a obtenção de discos de aproximadamente $1,5 \mathrm{~mm}$ de espessura (Figura 3). Os cortes dos discos foram realizados com disco diamantado de $102,0 \mathrm{~mm}$ de diâmetro e a,3 mm de espessura (Extec Corporation, XL-12205, USA), o qual era devidamente acoplado à máquina de corte, sendo refrigerado constantemente com água. A velocidade para corte foi de $300 \mathrm{rpm}$.

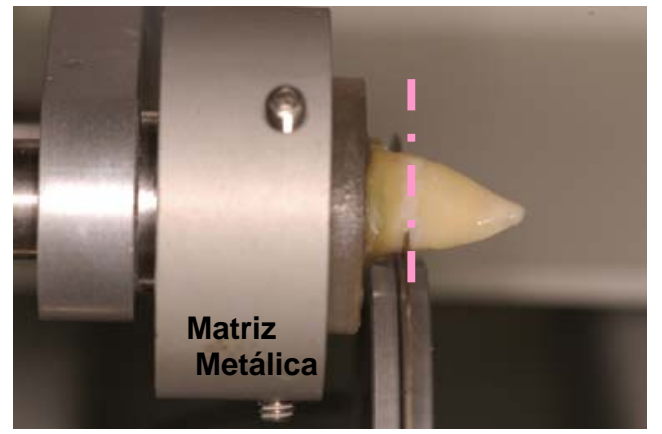

FIGURA 2 - Corte para a obtenção dos discos de dentina. 


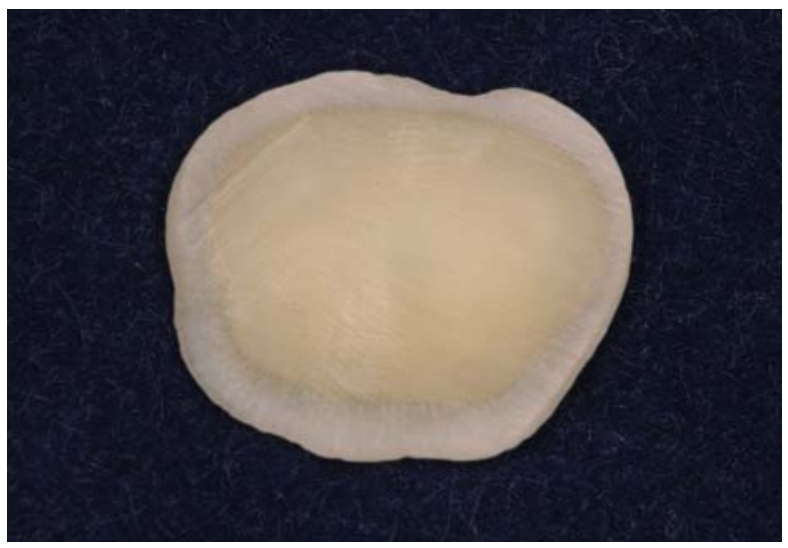

FIGURA 3 - Disco de dentina obtido após o segundo corte.

Os discos assim obtidos foram submetidos à regularização das suas superfícies com lixas de carbeto de silício (Buheler Ltda, Illinois, USA) de granulação 400 a 600, girando sobre uma politriz (Fortel Indústria e Comércio Ltda., Brasil), sob água corrente e pressão digital, a uma velocidade de $125 \mathrm{rpm}$. As superfícies dentinárias foram lixadas até que estivessem livres de remanescentes do esmalte coronário em sua superfície oclusal e sem quaisquer evidências de cornos pulpares na superfície pulpar dos discos e com espessura média de 0,97 \pm 0,08 mm. Para a comprovação da obtenção de uma superfície dentinária livre dos remanescentes indesejados, utilizou-se da Lupa Estereoscópica (Meji Techno Co. Ltda., Tokyo, Japan) e do paquímetro digital (Starrett Indústria e Comércio Ltda., São Paulo, Brasil) para a confirmação da espessura de cada disco de dentina. 


\subsection{Sistema de Medição da Condutividade Hidráulica}

Os ensaios quantitativos, de condutividade hidráulica foram feitos utilizando o sistema sugerido por PASHLEY e GALLOWAY ${ }^{69}$, em 1985, especialmente desenvolvido para a medição da permeabilidade dentinária, conforme se tem esquematizado na Figura 4.

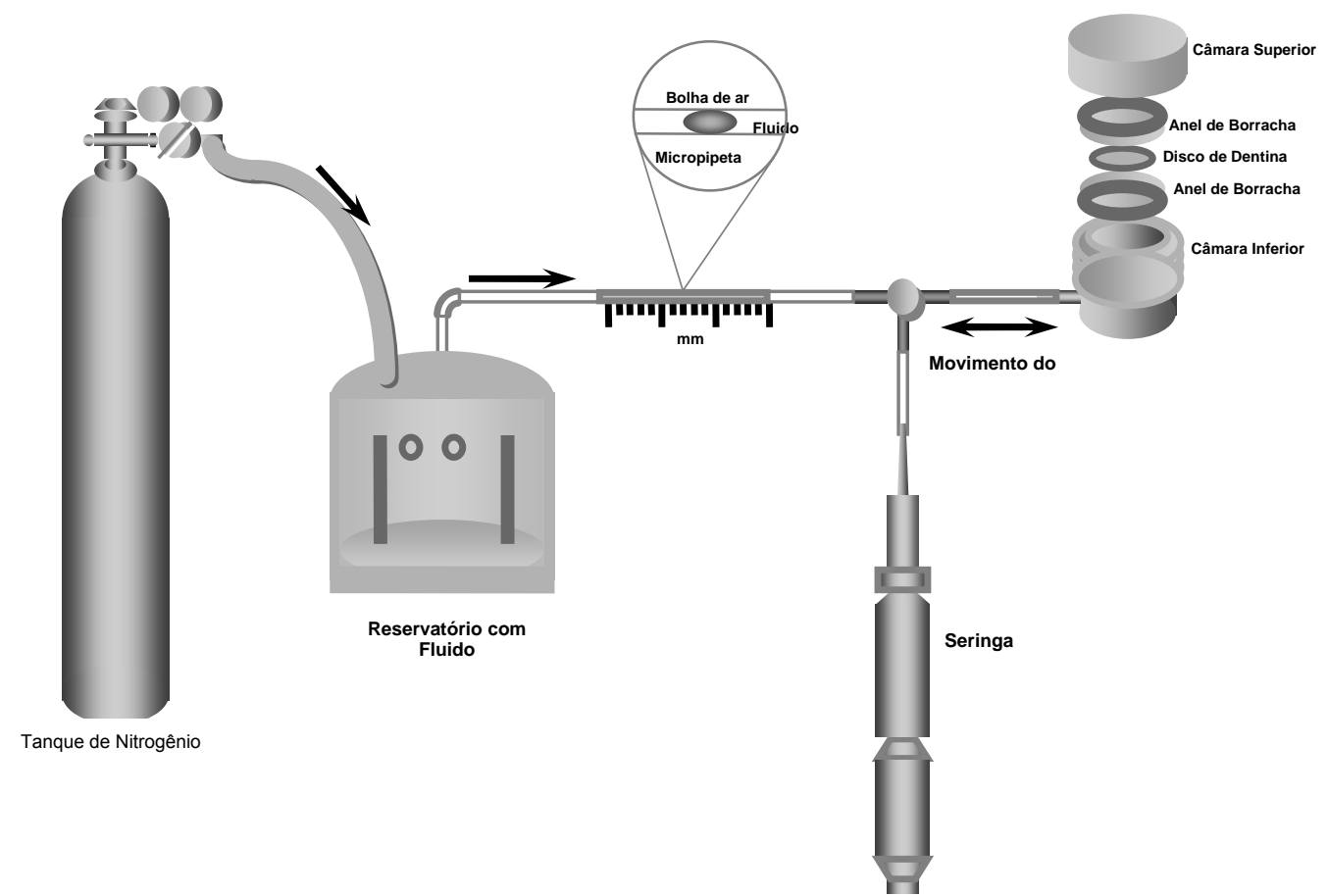

FIGURA 4 Representação esquemática do sistema utilizado para a medição da condutividade hidráulica da dentina. (adaptado de Pashley \& Galloway ${ }^{69}$ )

\subsubsection{Cilindro de Nitrogênio}

O nitrogênio, utilizado para a pressurização do sistema, é acondicionado em um cilindro de metal (White Martins, São Paulo, Brasil), que possui uma válvula para a liberação do nitrogênio e dois manômetros 
(White Martins, São Paulo, Brasil): um para monitorar a pressão interna do cilindro e outro, para determinar a pressão de trabalho, necessária para o movimento do líquido por todo o circuito.

Para o sistema começar a funcionar, a válvula para a liberação de nitrogênio é aberta e, a partir daí, o manômetro é regulado para determinar a pressão de trabalho, mantida constante durante todo o experimento em $703,1 \mathrm{~cm} \mathrm{H} \mathrm{H}_{2} \mathrm{O}$ ou 10 psi ou ainda $1,05 \mathrm{Kg} / \mathrm{cm}^{2}$.

\subsubsection{Câmara de Pressão}

A câmara de pressão é uma panela de pressão (Alcan Alumínio, 5,7 litros, Brasil) modificada para receber o condutor de pressão, um tubo de polietileno, proveniente do cilindro de nitrogênio. Um reservatório com capacidade para armazenar $600 \mathrm{ml}$ de água deionizada localiza-se no seu interior e recebe um capilar de polietileno que, por meio de um dispositivo de acoplagem localizado na tampa da câmara de pressão, comunica-se com o sistema capilar externo que conduzirá a água deionizada sob a pressão do nitrogênio. O volume da água deionizada foi freqüentemente reposto durante o procedimento. Importante mencionar que na tampa da câmara de pressão está adaptada uma válvula de segurança que permite a despressurização, se necessária. Por ser hermeticamente fechada, a câmara de pressão permite que a pressão, no seu interior e por todo o sistema capilar abastecido por água deionizada, seja mantida constante em $703,1 \mathrm{~cm} \mathrm{H} \mathrm{H}_{2} \mathrm{O}$. 


\subsubsection{Sistema de Capilar de Polietileno e Componentes para a Leitura}

O sistema de capilares (CPL Medical's Produtos Médicos Ltda., São

Paulo, Brasil) funciona como um elo entre a câmara de pressão e a câmara de filtração sendo que, neste percurso, encontram-se os componentes responsáveis pela leitura da filtração da água deionizada através da dentina: o capilar de vidro (Fisher Scientific Company, Pittsburgh, USA) e a microseringa (Gilmont Instruments Inc, Great Neck, New York, USA). O capilar de vidro, o qual possui $65 \mathrm{~mm}$ de comprimento e capacidade de $25 \mu \mathrm{l}$, encontra-se justaposto a uma escala de medição, em milímetros, que serve para medir o deslocamento do líquido numa fração de tempo, de acordo com a velocidade de filtração que se tem nos discos de dentina.

O deslocamento da água deionizada foi monitorado pelo movimento de uma bolha de ar, produzida pela micro-seringa, sobre uma régua milimetrada. A micro-seringa é composta por um reservatório com água deionizada e um cursor e encontra-se acoplada a uma extensão capilar de polietileno situada entre o capilar de vidro e a câmara de filtração. Tem as funções de formar a bolha de ar e posicioná-la adequadamente no capilar , ajustando-a na escala milimetrada, através da injeção ou retirada de água. $O$ deslocamento linear da bolha de ar representa o deslocamento volumétrico de líquido por minuto ( $\mu \mathrm{l} / \mathrm{min})$, através do disco de dentina. 


\subsubsection{Câmara de Filtração}

A câmara de filtração (Starrett Industria e Comércio Ltda., São Paulo, Brasil) é a porção final do sistema de medição, abrigando os espécimes de dentina, conectando-se à câmara de pressão através de capilares de polietileno. É formada por dois componentes de plexiglass, um superior e um inferior, sendo encaixados por rosqueamento. O componente inferior apresenta dois orifícios que são conectados, por meio de túbulos metálicos, a capilares de polietileno para a circulação do líquido pressurizado. Um dos tubos metálicos funciona como entrada do líquido sob pressão no segmento inferior da câmara. Outro é mantido vedado, destinando-se à drenagem do líquido para a remoção de eventuais bolhas de ar. O compartimento superior, encaixado por rosqueamento ao inferior, apresenta uma abertura central através da qual se tem acesso à superfície oclusal dos discos de dentina, onde são aplicados os materiais experimentais.

Os compartimentos da câmara são interligados por dois espaçadores, também de plexiglass, com abertura central de diâmetro padronizado, determinando áreas opcionais de superfície dentinária de 0,178 ou 0,282 $\mathrm{cm}^{2}$. Os discos de dentina eram adaptados entre os espaçadores, justapostos pelos anéis de borracha para vedação, dividindo a câmara de filtração em dois ambientes: um interno, interligado ao sistema de circulação de líquido e outro externo, voltado à superfície onde se realizaram os ensaios. Para se ter uma filtração padronizada do líquido, os discos foram posicionados tendo o lado pulpar voltado para o inferior, em contato direto dom o líquido sob pressão e o lado oclusal voltado à base superior. 


\subsection{Materiais e Condições Experimentais}

As bebidas testadas neste experimento (Figura 5) foram aplicadas sobre a superfície oclusal dos discos de dentina para se obter informações a respeito da capacidade que elas têm de desobstruir os túbulos dentinários a elas expostos. As bebidas e suas características são apresentadas Tabela 1.

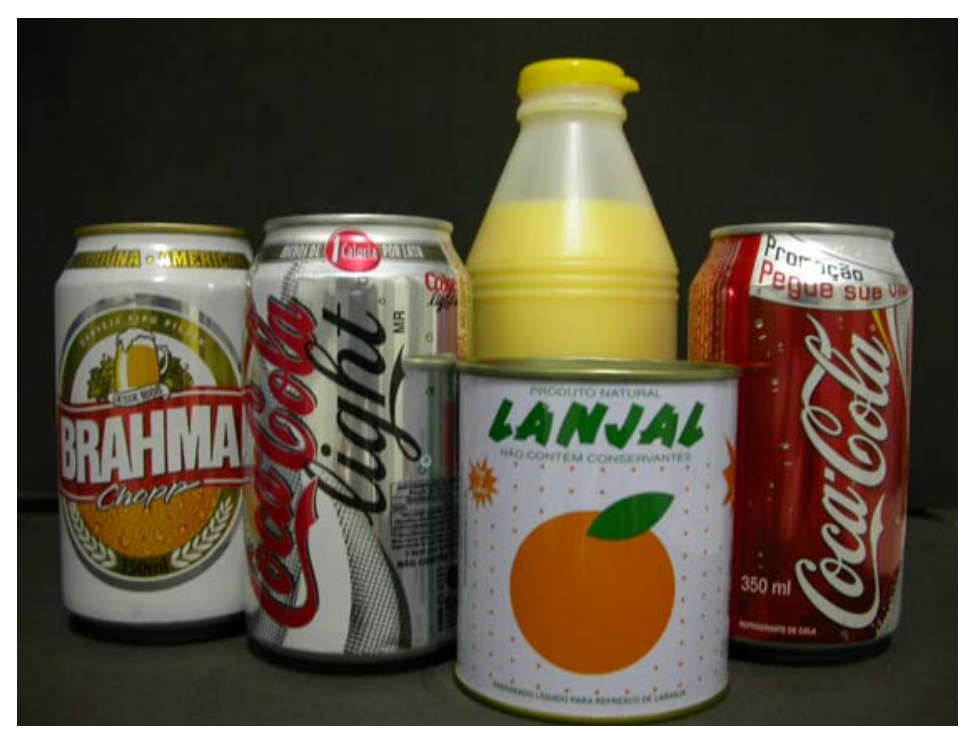

FIGURA 5 - Bebidas com teor ácido. 
TABELA 1 - Relação das bebidas testadas no experimento

\begin{tabular}{|c|c|c|c|}
\hline BEBIDAS & $\mathrm{pH}$ & Composição & Fabricante \\
\hline Coca Cola regular & 2,45 & $\begin{array}{l}\text { Água gaseificada, açúcar, extrato } \\
\text { de noz de cola, cafeína, corante } \\
\text { caramelo IV, acidulante INS } 338 \\
\text { e aroma natural. }\end{array}$ & $\begin{array}{c}\text { Coca Cola }^{\circledR}, \\
\text { Indústria Brasileira }\end{array}$ \\
\hline Coca Cola light & 2,66 & $\begin{array}{l}\text { Água gaseificada, extrato de noz } \\
\text { de cola, cafeína, corante } \\
\text { caramelo IV, edulcorantes } \\
\text { artificiais: ciclamato ( } 32 \mathrm{mg}) \text {, } \\
\text { aspatame ( } 12 \mathrm{mg} \text { ), sacarina ( } 6 \\
\text { mg) por } 100 \mathrm{ml} \text {, acidulantes } \\
\text { ácidos cítrico e fosfórico, aroma } \\
\text { natural, conservador benzoato de } \\
\text { sódio. }\end{array}$ & $\begin{array}{c}\text { Coca Cola }^{\circledR}, \\
\text { Indústria Brasileira }\end{array}$ \\
\hline $\begin{array}{c}\text { Suco de Laranja } \\
\text { Natural }\end{array}$ & 3,70 & & $\begin{array}{c}\text { Padaria } \\
\text { Copacabana, } \\
\text { Bauru/SP, Brasil }\end{array}$ \\
\hline $\begin{array}{c}\text { Suco de Laranja } \\
\text { Lanjal }^{*}\end{array}$ & 3,90 & $\begin{array}{l}\text { Suco de laranja concentrado, } \\
\text { açúcar, óleo especial de laranja, } \\
\text { aroma natural de laranja, corante } \\
\text { natural beta caroteno e água. }\end{array}$ & $\begin{array}{l}\text { Global bebidas e } \\
\text { alimentos Ltda. } \\
\text { Matão/SP, Brasil }\end{array}$ \\
\hline Cerveja Brahma & 3,87 & $\begin{array}{l}\text { Água, malte, cereais não } \\
\text { maltados, carboidratos e lúpulo. } \\
\text { Antioxidante: INS } 316 . \\
\text { Estabilizante: INS } 405 \text {. Glútem. } \\
\text { Teor alcoólico- 4,8\% em volume. }\end{array}$ & $\begin{array}{c}\text { Ambev, Indústria } \\
\text { Brasileira }\end{array}$ \\
\hline
\end{tabular}

* A diluição utilizada foi a recomendada pelo fabricante: 1 medida do suco concentrado : 9 medidas de água. 
Para a realização do trabalho, os 50 discos de dentina preparados da maneira já descrita anteriormente foram divididos em 5 grupos de 10 discos cada, correspondentes às 5 soluções acima descritas. Os espécimes foram em seguida, submetidos ao teste de condutividade hidráulica, de acordo com a seguinte seqüência:

1. na ausência de smear layer, após o condicionamento com EDTA a 0,5 M por 1 minuto;

2. na presença de smear layer no lado oclusal do disco após o lixamento desta superfície com lixa de granulação 600 , durante 5 segundos;

3. após a aplicação de uma das soluções testadas na superfície oclusal do disco durante 3 e 5 minutos respectivamente.

Do ponto de vista da ação das bebidas, é importante salientar que a medição de 5 minutos corresponde a 8 minutos de aplicação total da solução analisada sobre o disco de dentina, já que foram feitas duas medições: aos 3 minutos e em 5 minutos após a primeira mensuração. A seqüência deste experimento pode ser melhor compreendida através do Fluxograma 1. 
FLUXOGRAMA 1 - Seqüência de passos realizados para o teste da condutividade hidráulica.

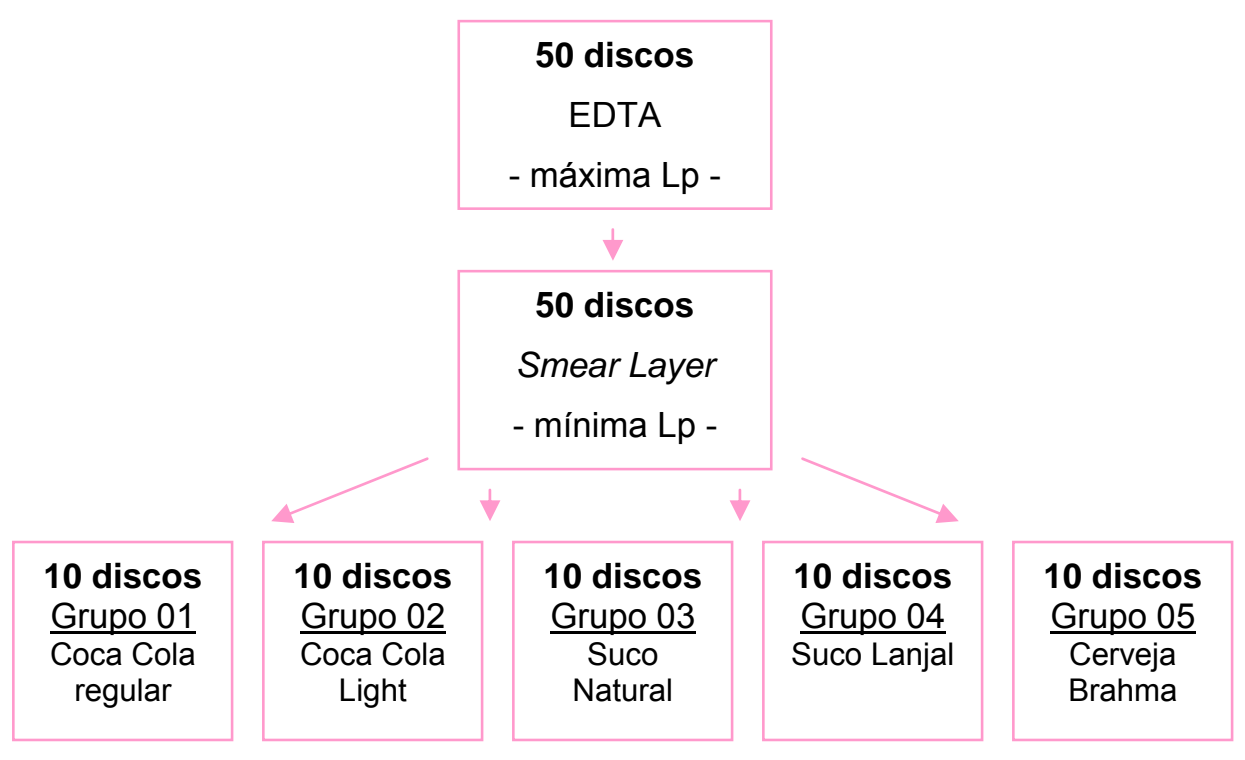

Para a obtenção dos resultados, foram realizadas quatro medidas do movimento da bolha através do capilar a fim de computar os valores médios para cada disco de dentina, antes e depois de cada tratamento. Os valores coletados foram descritos e organizados em uma ficha que continha, para todas as condições, a distância percorrida pela bolha e o tempo necessário para percorrê-la. Nesta mesma ficha, eram anotados os valores de condutividade hidráulica, a média aritimética das condutividades hidráulicas bem como seus valores relativos em porcentagem, como mostra o anexo 3. 


\subsection{Análise dos Resultados de Condutividade Hidráulica}

Após a obtenção dos valores de deslocamento da bolha e do tempo decorrido, procedeu-se ao cálculo da permeabilidade dentinária, expressa em termos de condutividade dentinária (Lp). Aplicou-se, para tanto, uma equação em que a velocidade e o tempo de deslocamento da bolha foram as variáveis, sendo calibre e volume do capilar, pressão hidrostática e área de superfície medidas de valores constantes.

Os valores Lp obtidos após a aplicação do EDTA representavam a filtração máxima $(100 \%)$, sendo os valores de Lp referentes às demais condições experimentais, calculados como uma proporção da permeabilidade máxima. Por ser assim, cada disco serviu como seu próprio controle, onde os valores de filtração na presença de smear layer, após a aplicação das soluções estabelecidas para as condições experimentais deterninadas, variavam percentualmente em relação ao valor obtido pós condicionamento com EDTA.

A seguinte equação foi então utilizada para o cálculo da condutividade hidráulica (Lp), expressa em $\mu \mathrm{cm}^{-2} \mathrm{~min}^{-1} \mathrm{~cm} \mathrm{H}_{2} \mathrm{O}$ :

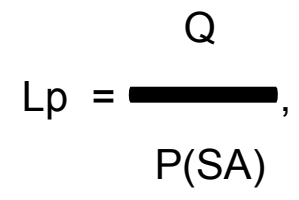

onde,

$$
\begin{aligned}
& \mathrm{Lp}=\text { condutividade hidráulica da dentina em } \mu \mathrm{cm}^{-2} \min ^{-1} \mathrm{~cm} \mathrm{H}_{2} \mathrm{O} \\
& \mathrm{Q}=\text { índice de filtração em } \mu \mathrm{min}^{-1} \\
& \mathrm{SA}=\text { área da superfície dentinária em cm }
\end{aligned}
$$


$\mathrm{P}=$ diferença da pressão hidrostática através da dentina em $\mathrm{cm} \mathrm{H} \mathrm{H}_{2} \mathrm{O}$

Tendo o capilar utilizado para medir índice de filtração (Q) um diâmetro constante, dividindo-se seu volume $(25 \mu \mathrm{l})$ pelo seu comprimento (65mm), obtém-se uma proporcionalidade constante que, relacionada com a distância percorrida pela bolha (x mm) e o tempo decorrido (y min), converte o deslocamento linear em volume deslocado, que podem ser expressas pela seguinte equação:

$$
Q=\frac{25 \mu \mathrm{l} \cdot(\mathrm{x}) \mathrm{mm}}{65 \mathrm{~mm} \cdot(\mathrm{y}) \mathrm{min}},
$$

A pressão hidrostática $(P)$ foi convertida em $\mathrm{cm} \mathrm{H}_{2} \mathrm{O}$ previamente ao cálculo dos valores de condutividade hidráulica (Lp) e, dessa forma, mantida constante durante todo o tempo do experimento em $703,1 \mathrm{~cm} \mathrm{H}_{2} \mathrm{O}$. A área de superfície (SA), determinada pelo diâmetro dos espaçadores da câmara de filtração e selecionada em dependência da dimensão dos discos de dentina disponíveis, era padronizada em 0,178 ou $0,282 \mathrm{~cm}^{2}$.

Sendo os valores da pressão, calibre e volume do capilar constantes no decorrer de todo o experimento, também com o objetivo de simplificar o cálculo da condutividade hidráulica (Lp), a determinação dos valores preliminares incluindo tais valores foram pré-definidos em duas equações específicas para cada área de superfície utilizada. Sendo assim, quando a 
área de superfície dentinária exposta pelo espaçador era de $0,282 \mathrm{~cm}^{2}$, a equação utilizada foi a número 1 e, para o espaçamento menor, de 0,178 $\mathrm{cm}^{2}$, utilizou-se da equação de número 2. Os cálculos de $\mathrm{Lp}$ foram realizados através do programa Microsoft Excel 97 (Microsoft Corporation, Redmond, USA)



(y)min
0,0030731909. (x)mm

$Q=$

(y)min

EQUAÇÃO 1 EQUAÇÃO 2

Para um maior conhecimento das soluções estudadas neste trabalho de pesquisa, realizou-se a titulação das mesmas.

\subsection{Preparação das amostras para Microscopia Eletrônica de Varredura}

Com a finalidade de observar as características da superfície dos discos tratados com as bebidas estudadas, foram preparados espécimes de dentina para cada grupo experimental, seguindo os mesmos passos adotados para os testes de condutividade hidráulica. Para tanto, discos com smear layer e discos tratados por 3 e 5 min com as diferentes bebidas experimentadas foram desidratados e metalizados para posterior observação em microscopia eletrônica de varredura.

Os espécimes foram montados em stubs metálicos (3M, Minnesota, USA) com dimensões apropriadas para a base do microscópio e, em seguida, mantidos em estufa por 24 horas, a $36^{\circ} \mathrm{C}$. Após esse período, os 
discos de dentina foram recobertos com ouro (Balzers, Germany) a uma espessura de $18 \mathrm{~nm}$, empregando o Sputter Coater (Beltzers SDC 050, Germany).

Foram obtidas fotomicrografias com aceleração de voltagem de $20 \mathrm{kV}$ e 1.000X de aumento, empregando o microscópio JEOL AT-2000 (JEOL, Japan).

\subsection{Planejamento Estatístico}

Diante da variabilidade biológica da dentina, da profundidade do esmalte e da altura dos cornos pulpares, um disco difere do outro. Isso induz aos dados uma variabilidade biológica inerente quando analisados como um grupo. Sendo assim, para que seja diminuída, os dados foram calculados como uma mudança percentual da condutividade hidráulica após cada etapa da seqüência experimental em relação ao valor máximo de $100 \%$ obtido pelo condicionamento com EDTA, sendo que cada disco foi utilizado como seu próprio controle.

As médias e o desvio padrão das mudanças percentuais na Lp foram calculadas.

Os resultados dos ensaios de condutividade hidráulica foram submetidos à análise de variância a dois critérios, com nível de significância de $5 \%$, aplicada aos valores médios percentuais, identificando as diferenças intergrupos e intragrupos. As diferenças individuais foram determinadas pelo teste Múltiplo de Duncan, também a um nível de significância de $5 \%$. 
5- RESULTADOS 


\section{5- RESULTADOS}

\subsection{Condutividade Hidráulica}

Os resultados dos ensaios de condutividade hidráulica foram submetidos à análise de variância a dois critérios, com nível de significância de $5 \%$, aplicada aos valores médios percentuais, identificando as diferenças intergrupos e intragrupos. As diferenças individuais foram determinadas pelo teste Múltiplo de Duncan, também a um nível de significância de $5 \%$, conforme descrito anteriormente.

Os valores médios de condutividade hidráulica (Lp) obtidos intragrupos e expressos em percentagem para as cinco soluções estudadas nos tempos experimentais de 3 e 5 minutos estão representadas na Tabela 2.

É importante salientar que os valores de permeabilidade obtidos quando a smear layer foi mantida representam a permeabilidade mínima de filtração, enquanto os valores encontrados pós condicionamento ácido com EDTA mostram os valores de permeabilidade máxima de filtração, ou seja, $100 \%$ individualmente para cada espécime. Além disso, para todos os materiais e em ambos os tempos, os valores de filtração obtidos na presença de smear layer e após a aplicação dos materiais avaliados são, em geral, significantemente menores que os obtidos frente ao EDTA. Pode-se observar também diferenças estatisticamente significantes entre a condutividade hidráulica para a smear layer e os sucos natural e artificial nos tempos de 3 e 5 minutos respectivamente. Essa diferença não é notada para 
os demais grupos, embora os valores percentuais de condutividade, após a aplicação da Coca Cola regular, Coca Cola light e Cerveja, sejam numericamente maiores que os obtidos com a smear layer.

TABELA 2 - Percentual médio e desvio padrão da permeabilidade dentinária (Lp) após a aplicação de diferentes bebidas com teor ácido (Duncan, $\mathrm{p}<0,05$ ).

\begin{tabular}{c|cccc}
\hline PERMEABILIDADE & EDTA & Smear layer & 3 minutos & 5 minutos \\
\hline Coca Cola regular & $100,00^{a}$ & $17,09^{b} \pm 12,66^{\circ}$ & $24,18^{b} \pm 15,52$ & $27,25^{b} \pm 16,08$ \\
\hline Coca Cola light & $100,00^{a}$ & $20,75^{b} \pm 15,20$ & $25,48^{b} \pm 20,04$ & $25,02^{b} \pm 18,71$ \\
\hline Suco Natural & $100,00^{a}$ & $14,76^{b} \pm 12,20$ & $38,20^{c} \pm 20,12$ & $45,32^{c} \pm 22,56$ \\
\hline Suco Artificial & $100,00^{a}$ & $16,13^{b} \pm 11,98$ & $35,79^{c} \pm 18,86$ & $41,90^{c} \pm 18,21$ \\
\hline
\end{tabular}

Valores com a mesma letra não possuem diferença estatisticamente significante.

A Tabela 3 e Gráfico 1, que nos mostram o comportamento de cada substância para o tempo de 3 minutos, nos permite ver que a Coca Cola regular, Coca Cola light e Cerveja não tiveram seus valores de filtração diferentes estatisticamente, o que não ocorreu quando comparadas aos sucos de laranja natural e artificial. Estes últimos promoveram valores de filtração significantemente maiores em comparação com as demais substâncias. Não há, porém, diferença significante entre os sucos natural e artificial. É Importante mencionar que o ácido fosfórico não foi incluído na 
análise para permitir uma real diferenciação entre os grupos experimentais de valores nitidamente mais baixos.

TABELA 3 - Variação, em pontos percentuais, da condutividade hidráulica para o tempo de 3 minutos, com resultado do teste de Duncan $(p<0,05)$.

\begin{tabular}{|c|c|c|}
\hline BEBIDA & Média & Desvio padrão \\
\hline Coca Cola regular & $7,09^{a}$ & 4,49 \\
\hline Coca Cola light & $4,74^{\mathrm{a}}$ & 6,00 \\
\hline Suco Natural & $23,44^{b}$ & 19,61 \\
\hline Suco Artificial & $19,66^{b}$ & 9,08 \\
\hline Cerveja & $2,97^{a}$ & 5,05 \\
\hline
\end{tabular}

GRÁFICO 1 - Variação, em pontos percentuais, da condutividade hidráulica em 3 minutos.

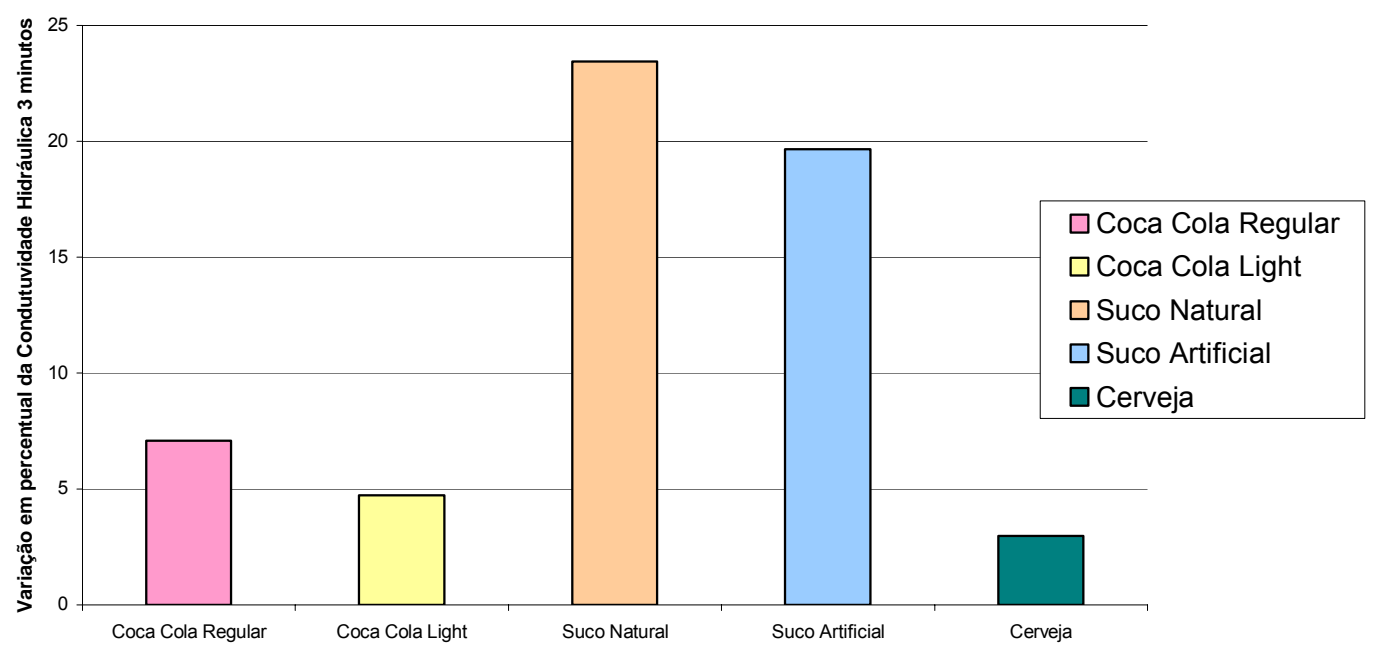

Avaliando-se os resultados mostrados na Tabela 4, nota-se as mesmas diferenças entre as bebidas de teor ácido após 5 minutos de aplicação adicional. O Gráfico 2 também evidencia tais observações. 
TABELA 4 - Variação, em pontos percentuais, da condutividade hidráulica para o tempo de 5 minutos, com resultado do teste de Duncan $(p<0,05)$

\begin{tabular}{ccc}
\hline BEBIDA & Média & Desvio padrão \\
\hline Coca Cola regular & $10,16^{a}$ & 5,33 \\
Coca Cola light & $4,28^{a}$ & 5,70 \\
Suco Natural & $30,56^{b}$ & 23,14 \\
Suco Artificial & $25,77^{b}$ & 9,79 \\
Cerveja & $3,66^{a}$ & 6,11 \\
\hline $\begin{array}{l}\text { Valores com a mesma letra não possuem } \\
\text { diferença estatisticamente significante. }\end{array}$
\end{tabular}

GRÁFICO 2 - Variação, em pontos percentuais, da condutividade hidráulica para o tempo de 5 minutos.

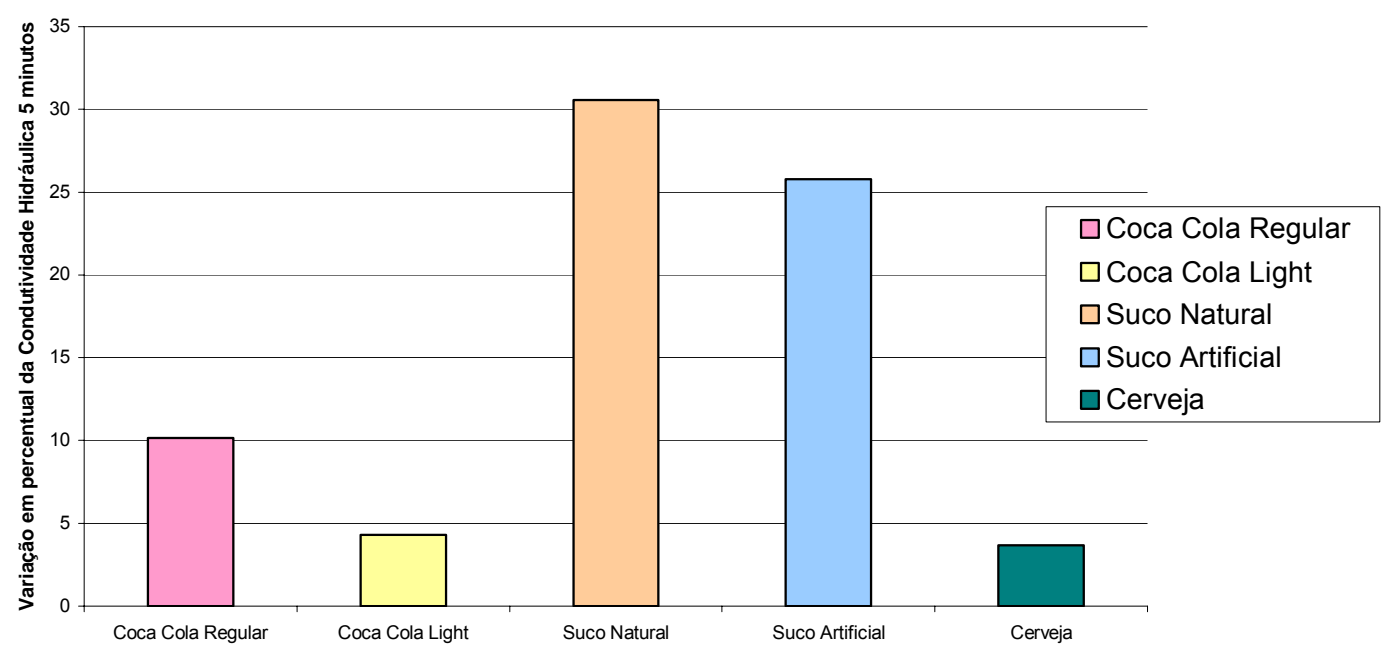

\subsection{Titulação das bebidas de teor ácido}

Com a finalidade de se observar as características de acidez, foi realizada a titulação de cada uma das soluções estudadas. Esses valores de titulação não foram correlacionados estatisticamente dom os resultados da condutividade hidráulica (Lp). As informações relativas à titulação tiveram 
apenas o objetivo de auxiliar na compreensão do processo de solubilização da smear layer produzido pelas bebidas de teor ácido. O interesse quanto a esse aspecto será discutido posteriormente. Os procedimentos de titulação foram realizados no Laboratório de Química da Faculdade de Ciências da Universidade Estadual Paulista - UNESP, campus de Bauru. O equipamento utilizado para aferir o $\mathrm{pH}$ foi o peagâmetro da marca MS Tecnopon, modelo PA 200.

A base utilizada para tanto foi o hidróxido de potássio $(\mathrm{KOH})$, a $0,1 \mathrm{~N}$ e, como indicador, a solução alcoólica de fenolftaleína.

Os valores da acidez titulável mostram a capacidade tampão de cada substância testada. Os maiores valores sugerem que essas substâncias com maior capacidade tampão conseguem manter-se em seu $\mathrm{pH}$ inicial por um intervalo de tempo mais longo.

A Tabela 5 e o Gráfico 3 mostram a quantidade (em $\mathrm{ml})$ de $\mathrm{KOH}$, $0,1 \mathrm{~N}$, necessários para $10 \mathrm{ml}$ de cada substância testada para atingir o $\mathrm{pH}$ 7,0 ( $\mathrm{pH}$ neutro). 
TABELA 5 - Volume necessário da base $\mathrm{KOH}$ (em $\mathrm{ml}$ ) para $10 \mathrm{ml}$ das bebidas de teor ácido atingirem $\mathrm{pH} \sim 7,0$.

\begin{tabular}{ccc}
\hline BEBIDA & $\mathrm{pH}$ inicial & Volume de $\mathrm{KOH}$ em ml \\
\hline Coca Cola regular & 2,45 & 1,80 \\
Coca Cola light & 2,66 & 2,60 \\
Suco Natural & 3,70 & 12,70 \\
Suco Artificial & 3,90 & 3,70 \\
Cerveja & 3,87 & 3,40 \\
\hline
\end{tabular}

GRÁFICO 3 - Volume (em ml) de solução alcalina $(\mathrm{KOH})$ necessária para $10 \mathrm{ml}$ das bebidas com teor ácido atingirem $\mathrm{pH} \sim 7,0$.

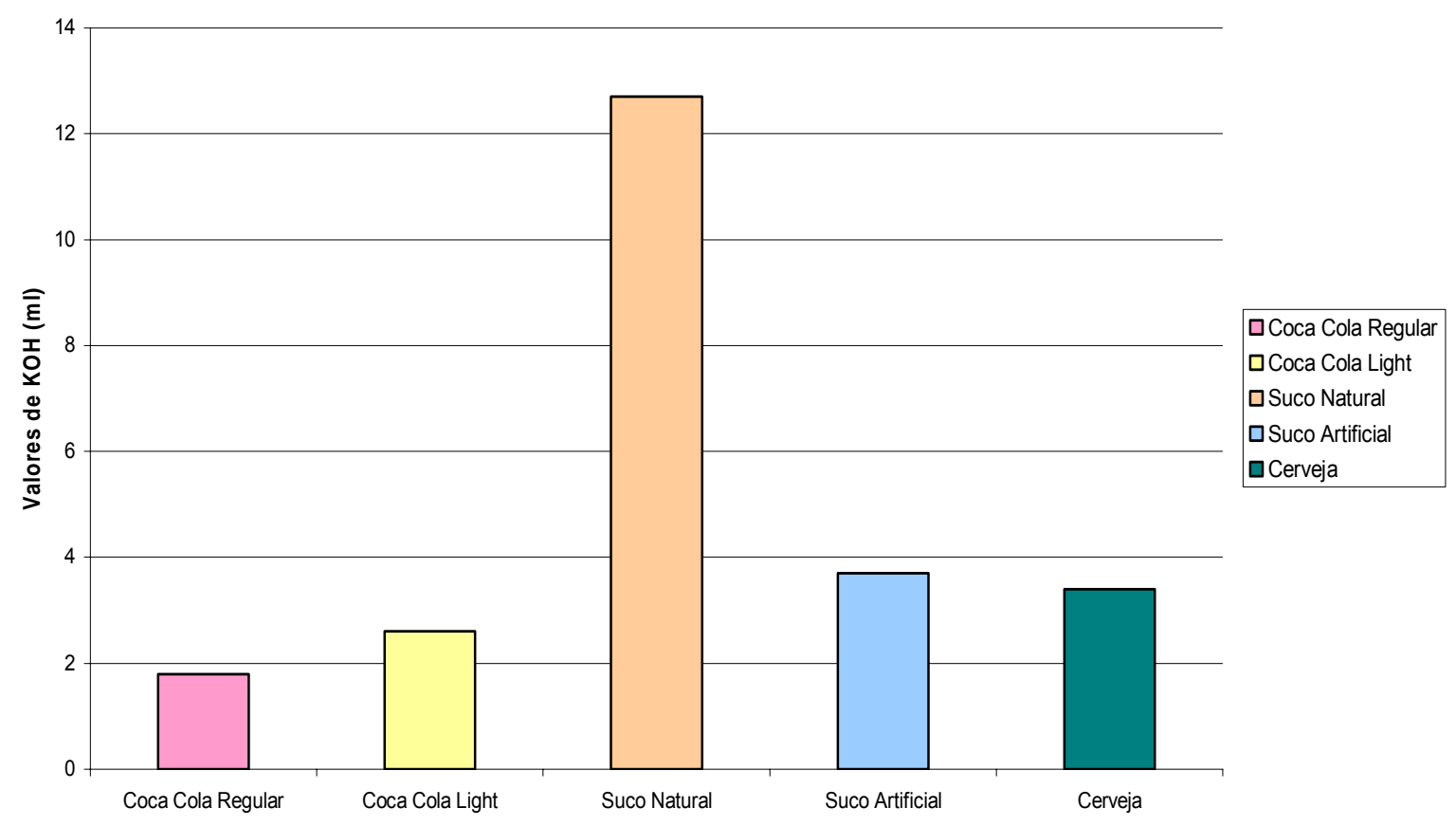




\subsection{Microscopia eletrônica de varredura}

As fotomicrografias eletrônicas de varredura mostraram similaridade com os resultados obtidos nos testes de condutividade hidráulica da dentina. Os espécimes não tratados, com a presença de smear layer revelam imagem de túbulos totalmente obstruídos por esta camada (Figura 6). No entanto, diferenças, embora pequenas em alguns espécimes, são possivelmente observadas nos espécimes tratados pelas bebidas de teor ácido com relação àqueles não tratados. Os espécimes que mostraram maior exposição da embocadura dos túbulos dentinários foram aqueles submetidos aos sucos de laranja. O suco natural exerceu solubilização mais acentuada da smear layer quando comparado ao suco artificial, havendo diferenças na exposição dos túbulos para os tempos de 3 e 5 minutos (Figuras 7 e 8). Em relação às Coca Colas, cujas imagens das fotomicrografias podem ser vistas nas Figura 9 e 10, os efeitos foram menores, respectivamente, para os espécimes da Coca Colar Regular e Coca Cola light. Para a Cerveja (Figura 11), pouca alteração foi notada quando em comparação aos espécimes com smear layer, nos os túbulos dentinários apresentaram-se completamente obstruídos pelos resíduos do lixamento da superfície dentinária. 


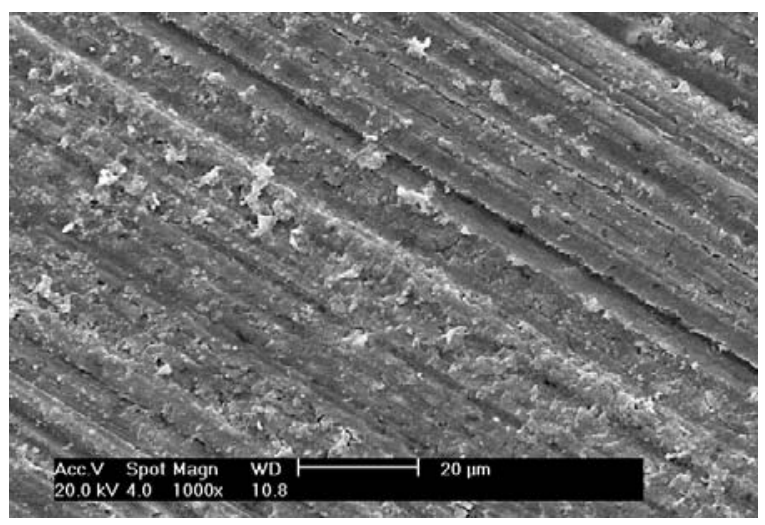

FIGURA 6 - Superfície não tratada, com aparência característica da smear layer.
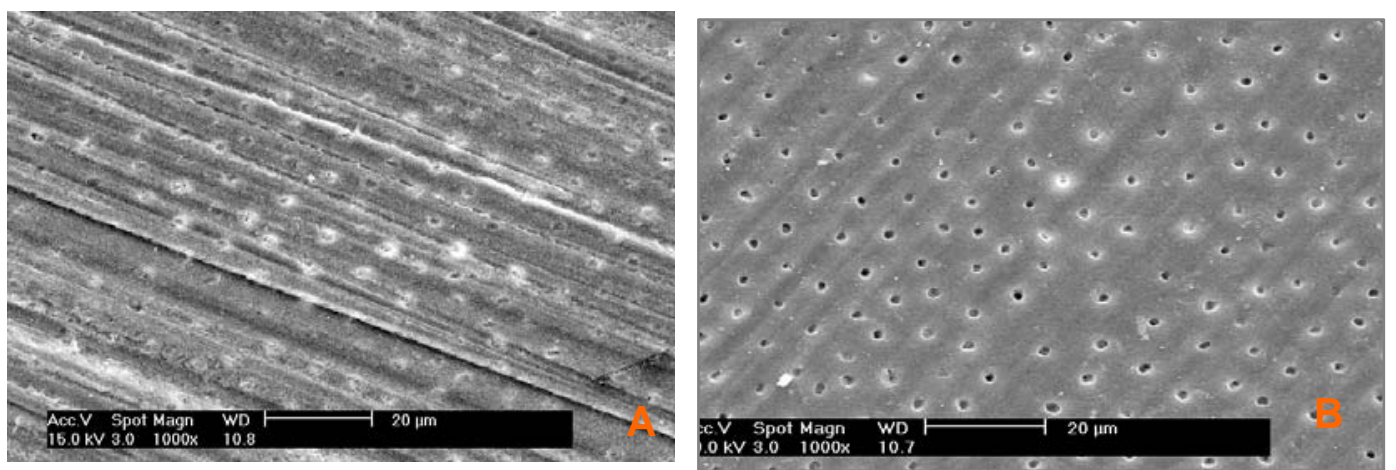

FIGURA 7 - O grau de exposição tubular é claramente mais visível nesses espécimes tratados com o suco artificial por $3(\mathrm{~A})$ e 5 minutos $(\mathrm{B})$, respectivamente.
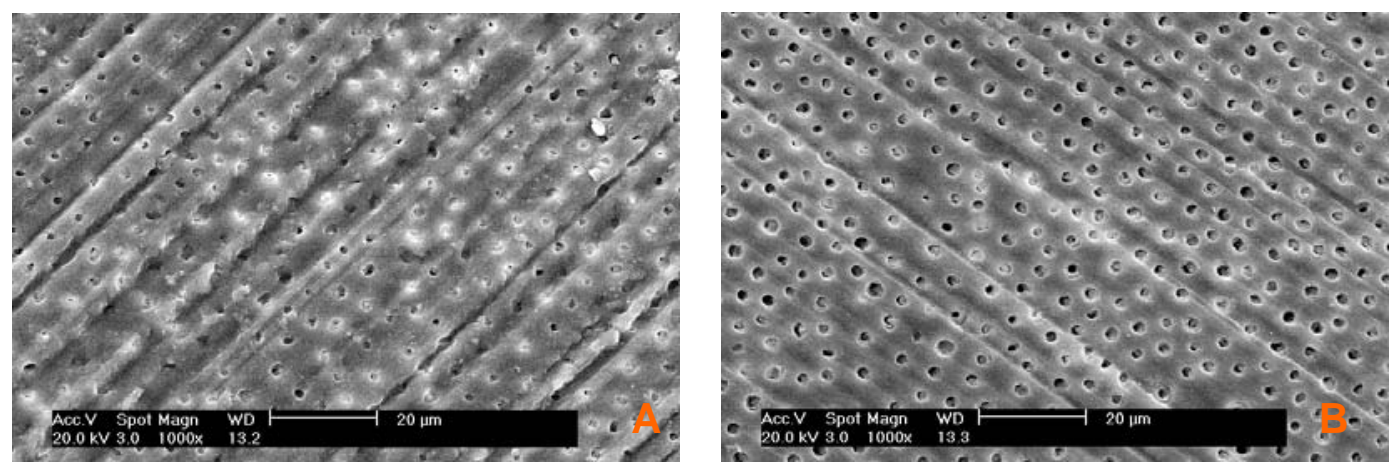

FIGURA 8 - O suco de laranja natural removeu mais intensamente a smear layer, permitindo a visualização quase completa dos túbulos dentinários, mais acentuadamente após 5 minutos (B). 

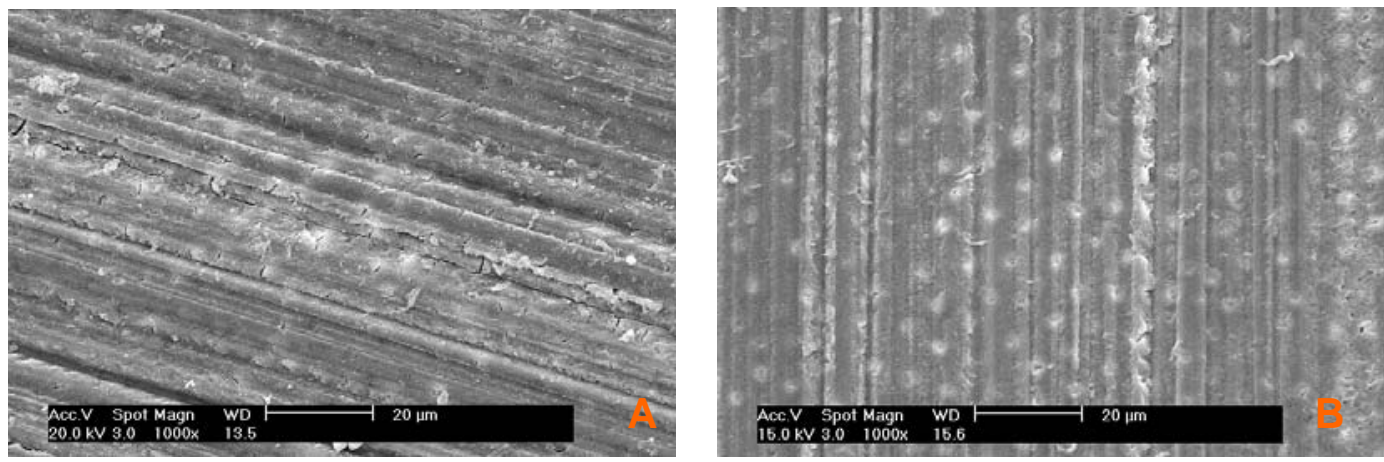

FIGURA 9 - Espécimes representativos da Coca Cola light. Observar em (A) a tênue exposição da superfície dentinária, permitindo a visualização de poucos espectros dos túbulos dentinários. Em (B) a localização dos túbulos é mais evidente, embora ainda obstruídos pelos smear plugs.
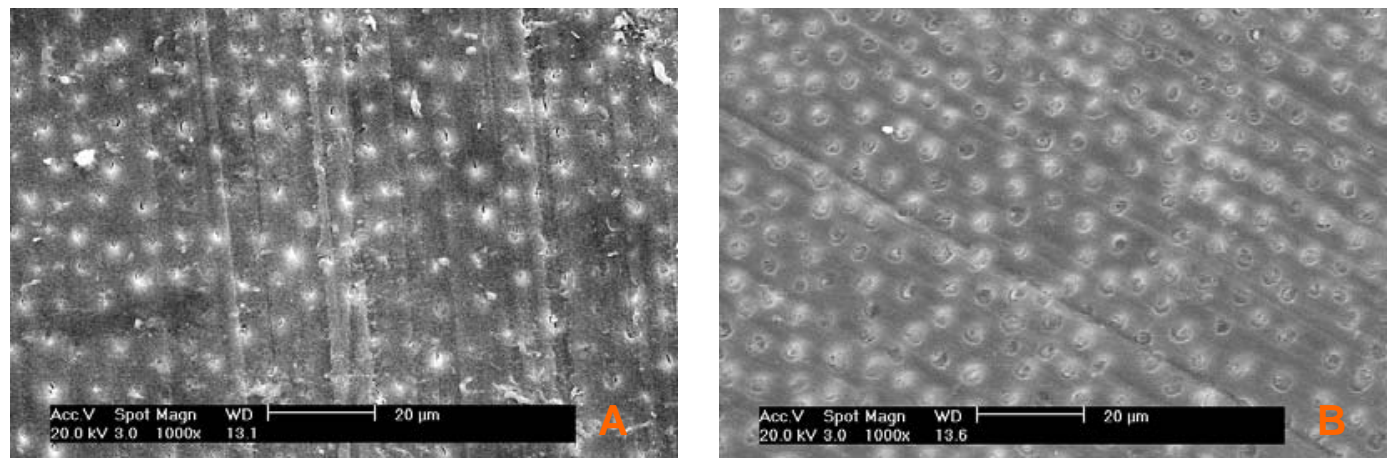

FIGURA 10 - Comparativamente com a Coca Cola light, os espécimes da Coca Cola regular mostram exposição mais acentuada dos túbulos dentinários, para ambos os tempos ( $\mathrm{A}$ e $\mathrm{B}$, respectivamente).
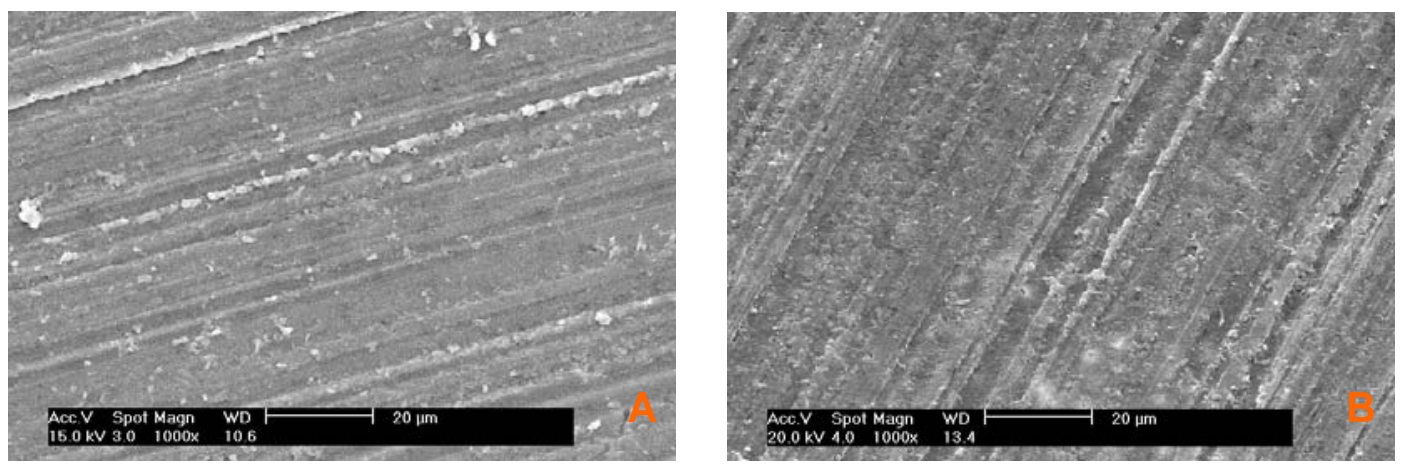

FIGURA 11 - Discos tratados com Cerveja. Em (A), após 3 minutos e em (B) após 5 minutos. Não há diferença notável de ambos os tempos, em comparação com a smear layer. 


\section{6- DISCUSSÃO}

\subsection{Da Metodologia}

A hiperestesia dentinária é um fenômeno sensorial complexo, que depende de fatores fisiológicos e emocionais que, ainda hoje, não estão completamente definidos e compreendidos. A teoria mais aceita para explicá-la é a Teoria da Hidrodinâmica, sendo necessário seu entendimento para que se compreenda, da melhor forma possível, os eventos que podem estar relacionados ao desencadeamento de todo o mecanismo envolvido na hiperestesia dentinária.

Acredita-se que os fatores que podem estar mais comumente associados a esta entidade, como definiu PEREIRA ${ }^{74}$, em 1995, são a erosão, abrasão, atrição, abfração assim como a associação entre os mesmos, que levam todos à perda de estrutura dentária por lesões não cariosas. No entanto, dentre os fatores citados, inúmeros estudos têm relatado ser a erosão química o principal fator desencadeador da perda de estrutura dentária e, conseqüentemente, o principal fator que pode estar envolvido na ocorrência da hiperestesia dentinária ${ }^{4,14,19,20,33,41,47,48,50,51}$. Por ser assim, o entendimento dos fatores que podem levar à erosão química dos dentes seria um caminho para se prevenir a hiperestesia visto que, dessa forma, os profissionais da saúde poderiam orientar seus pacientes a respeito de uma dieta mais adequada assim como sobre os demais fatores que podem estar interagindo com ela para a ocorrência da lesão. 
Há, certamente, várias bebidas de teor ácido que podem atuar na dissolução das estruturas dentárias mineralizadas. Entretanto, as empregadas no presente estudo foram escolhidas por serem amplamente consumidas pela população em geral. Seus efeitos sobre as estruturas dentárias dependem de suas características químicas individuais, da freqüência e do tempo que atuam sobre as estruturas dentárias, da maneira como são consumidas, da capacidade tampão da saliva e de fatores subseqüentes à ingestão como hábitos de higiene oral, etc.

Uma vez exposta, a dentina sofre o permanente desafio imposto por tais soluções ácidas, que tendem a superar os mecanismos naturais de obstrução dos túbulos dentinários. Por essa razão, é muito comum o relato de sensibilidade dentinária após o consumo de frutas cítricas ou outras bebidas de teor ácido.

Entendendo que a hiperestesia dentinária tem como causa as características hidrodinâmicas da dentina, a observação do efeito de determinadas bebidas na condutividade hidráulica dessa estrutura dentária pode trazer informações importantes para a compreensão e controle desse importante evento clínico. PRATI et al. ${ }^{81}$, 2003, que observaram, por microscópio eletrônico de varredura, que as bebidas ácidas, como o suco de laranja, podem provocar a abertura dos túbulos dentinários, deixando-os mais permeáveis e proporcionando condições similares àquelas encontradas nos casos de hiperestesia dentinária.

O potencial erosivo do suco de laranja, em que um dos componentes principais é o ácido cítrico, foi amplamente discutido por inúmeros trabalhos 
1,36,49,58,84,89. Ainda assim, a relação de bebidas ácidas com a permeabilidade dentinária ainda é pouco discutida.

No que diz respeito ao suco de laranja, é interessante destacar a diferença entre o produto natural e o concentrado artificial. É esperado que o suco natural tenha uma concentração ácida maior que a do suco artificial, o qual necessita de um certo grau de diluição. De fato, considerando a experiência de CAIRNS et al. ${ }^{14}, 2002$, a diluição do suco antes do consumo pode reduzir o seu potencial de solubilização, já que proporciona menores valores de acidez titulável. É importante destacar que, nesse trabalho, foi utilizada a diluição sugerida pelo fabricante para determinado volume de suco artificial.

A Coca Cola, por sua vez, apresenta em sua composição o ácido fosfórico e o ácido cítrico, conforme a sua apresentação, regular ou light. Como mencionado anteriormente, é uma bebida de amplo consumo social e a sua formulação light tem grande aceitação por razões ligadas principalmente à estética física. Segundo informações do fabricante das Coca Colas, todo refrigerante contém uma pequena quantidade de ácido e os mais utilizados são, de fato, o ácido cítrico e o ácido fosfórico. Entretanto, essas bebidas não têm acidez suficiente para causar danos ao organismo, uma vez que o próprio suco gástrico tem um teor ácido maior que o presente nos refrigerantes. Com relação ao esmalte, concluem que a saliva, contendo íons de cálcio e fosfato, pode compensar as eventuais perdas minerais provocadas pela ingestão desses refrigerantes. Obviamente, esta opinião dos fabricantes atende apenas aspectos isolados do complexo problema 
relacionado com a solubilização do esmalte e, possivelmente, da dentina. Como já se mencionou anteriormente, há diferentes situações que não apenas a capacidade tampão da saliva com efetiva participação no equilíbrio das reações orgânicas à ingestão de produtos ácidos.

Vários trabalhos confirmam a capacidade erosiva desta bebida ${ }^{20,45,85}$. Porém, são poucos os que correlacionam o potencial erosivo dessa bebida de teor ácido com a permeabilidade dentinária e o aumento da sensibilidade nessa estrutura do dente.

Não há informações, na literatura, relativas ao consumo de Cerveja e seus eventuais efeitos sobre as estruturas dentárias. Um dos poucos trabalhos que fazem referência à Cerveja ${ }^{89}$, não tecem considerações mais profundas sobre os efeitos dessa bebida, quer sobre a solubilização do esmalte e da dentina, ou com relação à produção de sensibilidade dentinária. A Cerveja foi utilizada na presente pesquisa por ser, também, bebida de alto consumo pela população brasileira. Não há disponibilidade de informações suficientes para se conhecer com exatidão a composição dessa, assim como das demais bebidas comerciais. Sabe-se, entretanto, que é uma bebida carbonatada e que apresenta cerca de $4,8 \%$ de álcool em sua composição. A adição de dióxido de carbono, formando ácido carbônico em solução, diminui o $\mathrm{pH}$ e aumenta a capacidade tampão ${ }^{20}$.

A permeabilidade dentinária, amplamente estudada, é o fator primordial na ocorrência da hiperestesia dentinária, como explicada pela Teoria da Hidrodinâmica. Esta tem por base os estudos de Brännström ${ }^{10} \mathrm{e}$ Garberoglio e Brännström ${ }^{26}$, que sustentam o fato de que alterações da 
hidrodinâmica dos fluidos no interior dos túbulos, nas regiões de dentina exposta, poderiam causar sensibilidade. Frente a um estímulo externo, o fluido pulpar dentinário se movimentaria através da estrutura dentinária, estimulando as terminações nociceptoras na periferia do tecido pulpar.

A revisão de literatura sugere que, ao menos durante os primeiros anos de pesquisa sobre a hiperestesia dentinária, as técnicas in vitro se desenvolveram a passos mais rápidos que a investigação clínica, abrindo novas possibilidades de pesquisa. Isso pode sugerir que as pesquisas laboratoriais tornam-se imprescindíveis para a compreensão e explicação dos resultados in vivo. PASHLEY et al. ${ }^{72}$, em 1981, comparando a permeabilidade de dentes de cães in vitro e in vivo, concluíram que o estudo da permeabilidade dentinária in vitro é mais conveniente, uma vez que variáveis importantes, bem como algumas características de superfície da dentina, podem ser mais facilmente controladas.

Segundo estudos ${ }^{71,73}$, a mensuração da permeabilidade dentinária pode ser feita quantitativamente mediante três coeficientes independentes: a condutividade hidráulica, metodologia adotada neste trabalho, coeficiente de permeabilidade dos solutos ou ainda através do coeficiente de reflexão dos solutos. A condutividade hidráulica quantifica o movimento de fluido através dos túbulos dentinários, sendo sua execução relativamente fácil. Permite a padronização de variáveis importantes como a área da superfície dentinária, a espessura da dentina e a pressão hidrostática aplicada ${ }^{87}$, possibilitando a obtenção de resultados confiáveis. 
Para a obtenção dos discos de dentina, optou-se por $3^{\text {os }}$ molares não irrompidos de pacientes jovens por serem dentes que apresentam quantidade mínima de dentina secundária e esclerosada. Além disso, a escolha de um grupo específico de dentes possibilita a minimização da grande variação de permeabilidade de dente para dente e de uma região para outra de um mesmo dente, o que poderia interferir negativamente na obtenção dos resultados finais ${ }^{31,94}$.

Apesar de existirem outras soluções indicadas à armazenagem dos dentes como o azido de sódio ${ }^{67,68}$, o presente trabalho optou pela solução de timol, já utilizadas e comprovadas por outros estudos ${ }^{53,104}$. A preocupação em se utilizar uma solução ideal a este tipo de teste reside no fato de que o processo de armazenamento poder interferir nos valores de permeabilidade dentinária ${ }^{31} \mathrm{e}$, conforme estudos. A solução de timol não exerce efeito no conteúdo orgânico nem no inorgânico da dentina, além de ser eficaz contra o crescimento bacteriano.

O tempo de armazenagem dos dentes foi de, no máximo, 30 dias, aceitando-se os resultados divulgados por GOODIS; MARSHALL e WHITE, 1993, relataram que o tempo de armazenamento prolongado dos dentes pode interferir na permeabilidade dentinária, reduzindo-a, levando assim a resultados alterados.

O formato de discos para a obtenção dos espécimes foi preferido à forma de segmentos coronários visto que, de acordo com GILLAN, MORDAN e NEWMAN, $1997^{30}$, apesar de suas limitações, os disco de dentina são um sistema reconhecidamente adequado para experimentar, in 
vitro, efeitos de substâncias no deslocamento do fluido através da dentina. Além disso, é possível obter espécimes com espessura uniforme, concedendo-lhes características que o elegem como um modelo reprodutível e adequado a este tipo de experimento. O método para a obtenção destes discos foi descrito pela primeira vem em 1976 por OUTHWAITE, LIVINGSTON e PASHLEY ${ }^{63}$, que seccionavam transversalmente coroas de $3^{\text {os }}$ molares com o auxílio de brocas diamantadas em alta rotação, com adequada refrigeração. Entretanto, esse método é pouco eficiente para a padronização e acabamento dos espécimes obtidos; daí a preferência pelo método de obtenção em que se utiliza uma máquina de corte específica e discos de diamante para a secção.

Apesar dos cuidados mencionados, os discos apresentam uma permeabilidade heterogênea, conforme PASHLEY, em $1987^{66}$, relatou em seu experimento. Sendo assim, para compensar a variabilidade regional da dentina de um disco para outro e nas diferentes regiões de um mesmo disco, utilizou-se a maior área de superfície possível de cada disco para a realização do teste. O centro dos discos, em geral, superestimam os valores de Lp, uma vez que os anéis de borracha podem coincidir, mesmo que parcialmente, com áreas de corno pulpar ${ }^{66}$. Optou-se, portanto, nesse experimento pelos discos com área de $0,282 \mathrm{~cm}^{2}$ que permitia então a filtração através da quase total superfície do disco. Outro aspecto positivo desse método é que cada disco foi utilizado como seu próprio controle, permitindo comparações praticamente isentas de variáveis entre a $L p$ inicial e aquela obtida após a ação das bebidas com teor ácido. 


\subsection{Dos Resultados}

Os resultados obtidos para todos os espécimes nas condições e tempo estudados foram transformados em valores percentuais para permitir a compreensão das diferenças proporcionais entre as várias condições estudadas $^{34}$.

A literatura é vasta no que se refere ao estudo da hiperestesia dentinária, sendo vários os experimentos que buscam determinar as causas bem como o melhor tratamento para essa ocorrência clínica de origem multifatorial 4,5,47,74,76,92,100,101. A degradação das estruturas dentárias, embora de origem multifatorial, tem uma das suas causas mais prováveis a erosão química do esmalte e da dentina. Dentre as causas erosivas mais freqüentemente relatadas, encontra-se a ingestão de bebidas de teor ácido, seja por sua ação direta sobre as estruturas dentárias ou por sua interação com deficiências orgânicas do indivíduo.

De fato, ao se analisar os resultados da Tabela 2, observa-se que a condutividade hidráulica da dentina se altera sensivelmente e de forma diferente entre as bebidas estudadas. Quando se atenda para as variações de permeabilidade obtidas com a Coca Cola regular, nota-se um visível aumento da condutividade hidráulica dentinária após 3 e 5 minutos, em comparação com os valores obtidos na presença de smear layer. A despeito de serem diferenças não significantes estatisticamente, é razoável considerar o efeito dessas bebidas na diluição da smear layer. Esse efeito pode ser entendido como resultado de sua composição e apresentação, isto é, a presença de ácido fosfórico e suas características de carbonatação. Até 
onde se conhece da formulação dessa bebida, ela contém uma baixa porcentagem de ácido fosfórico (entre 1,5 e 3\%), o que lhe confere o pH 2,5. Sabe-se, entretanto, que não apenas $\mathrm{opH}$ relativamente baixo influi na capacidade solubilizadora dessa bebida, mas também, como já foi mencionado anteriormente, apresentação gaseificada. É possível que a liberação e a movimentação de bolhas de dióxido de carbono, que também faz parte de sua formulação, potencialize a ação solubilizadora do ácido ${ }^{20}$. Isso vale para todas as bebidas gaseificadas, de natureza cítrica ou não. Pelo menos no que diz respeito ao esmalte, a erosão dental causada por ácidos provenientes da dieta é uma interação de fatores com $0 \mathrm{pH}$, concentração do ácido e a presença de cálcio na solução ${ }^{41}$. Em condições semelhantes às estudadas no presente trabalho é possível imaginar que o ácido atue sobre a superfície dentinária, dissolvendo a smear layer e deslocando os seus componentes com movimento de bolhas gasosas.

É importante considerar, para todos os grupos experimentais e seus efeitos sobre a permeabilidade da dentina, a ação importante do tempo em que as estruturas dentárias, no caso, a dentina, são submetidas à ação das bebidas. Os tempos aqui experimentados não encontram respaldos na literatura, mas sim, representam uma opção que simula o tempo aproximado de contato das bebidas com as estruturas dentárias durante um dia de consumo alternado. É importante considerar ainda que o tempo adicional de 5 minutos, empregado como segunda variável temporal representa, na verdade, 8 minutos de ação sobre os discos de dentina. É possível que tempos mais longos pudessem proporcionar maiores valores de 
permeabilidade. Ainda assim, os tempos empregados permitiram constatar as variações da condutividade hidráulica da dentina.

O mesmo que já se discutiu para a Coca Cola regular, pode ser aplicado para a Coca Cola light. Ao se observar a composição disponibilizada na embalagem desse produto, constata-se que sua formulação é mais complexa que da Coca Cola regular e que suas substâncias acidulantes são ácido fosfórico e ácido cítrico. No entanto, o pH dessa bebida é muito próximo daquele proporcionado pela Coca Cola regular. Possivelmente, essa formulação mais complexa proporcione menor efeito na condutividade hidráulica da dentina, como se pode ver na Tabela 2. Entretanto, não há basicamente diferenças entre as duas formulações na forma que foram aqui estudadas. Esses resultados coincidem com os relatados por EDWARDS et al., em $1999^{20}$, que não encontraram diferenças entre as versões diet e regular da Coca Cola, apesar da presença de carboidrato refinados na formulação diet que podem aumentar a produção de ácido no meio bucal.

Efeito mais dramático é notado para os sucos de laranja natural e artificial. Os resultados da Tabela 2 mostram que a condutividade hidráulica da dentina, após diferentes tempos experimentais empregando essas bebidas, apresentaram valores significantemente maiores do que aqueles obtidos na presença de smear layer. Isso sugere que o ácido cítrico, natural componentes dessas bebidas tenha maior poder de solubilização da smear layer e, provavelmente, da própria dentina. É interessante observar que o pH tanto do suco natural como do artificial é nitidamente mais elevado do que o 
dos refrigerantes estudados, de acordo com o que se pode ver na Tabela 5. Como mencionado por HUGHES, $2000^{41}$, o pH, a concentração e a presença de cálcio são fatores essenciais no processo de solubilização das estruturas dentárias. De fato, ao se observar a titulação dessas bebidas, observa-se que os sucos cítricos aqui estudados apresentam valores de titulação mais altos que as demais bebidas (Tabela 5). Isso significa que as bebidas cítricas precisam de maior concentração de base para alcançar a ponto de equivalência das soluções. Conquanto a Tabela 2 mostra as comparações intragrupos, dando uma idéia genérica do potencial de ação dessas bebidas sobre a dentina, as Tabelas 3 e 4 dão a clara visão das diferenças intergrupos para os dois tempos estudados. Assim, pode-se observar a maior capacidade de desobstrução dos túbulos dentinários evidenciada pelo suco de laranja natural e artificial. Deve-se salientar que os valores encontrados nessas mencionadas tabelas representam as diferenças entre os percentuais e condutividade hidráulica entre a smear layer e os tempos de 3 e 5 minutos, respectivamente. Essa conduta permite uma interpretação mais real das diferenças intra e intergrupos por causa das variações naturais dos valores de condutividade obtidos com a smear layer entre os diferentes grupos.

Outros autores também relataram essa diferença de ação entre as bebidas carbonatadas artificiais e os sucos cítricos. EDUARDS et al ${ }^{20}$ também observaram que, embora os sucos puros de frutas cítricas tenham um $\mathrm{pH}$ inicial mais elevado do que as bebidas carbonatadas, eles requerem maior quantidade de base para aumentar o pH. Esses dados coincidem com 
outros encontrados na literatura, que relatam o maior potencial erosivo dos sucos cítricos comparativamente às bebidas do tipo "cola" 35,37 . Por tanto, não é apenas o pH da solução que é importante no processo de erosão, mas tam,bem a sua acidez titulável. Como foi mencionado, acidez titulável é a quantidade de alcalinos necessários para neutralizar o $\mathrm{pH}$ de determinada substância. Isso representa a quantidade de ácido disponível na solução, o que é uma indicação de seu potencial erosivo ${ }^{89}$. Segundo esse autores, as bebidas do tipo "cola" são consideradas de médio potencial erosivo, as bebidas cítricas, com alto potencial e a Cerveja com baixa capacidade erosiva.

Os valores encontrados nas Tabelas 2, 3 e 4 para Cerveja sugerem que, considerando a metodologia empregada, essa bebida tem pouco efeito na solubilização da smear layer, apesar da concentração ácida dessa bebida ser semelhante a do suco artificial. Estatisticamente, os valores encontrados para essa bebida são semelhantes aos encontrados para as bebidas tipo "cola" estudadas, embora numericamente menores. Independente da natureza acídica da Cerveja, encontra-se, na literatura, informações de que a simples adição de dióxido de carbono é capaz de aumentar a capacidade tampão das bebidas. Isso vale inclusive para a água gaseificada sem qualquer outro componente de definição de sabores.

As fotomicrografias eletrônicas de varredura mostraram como resultado algo coerente com o que foi observado nos testes de condutividade hidráulica da dentina. Os espécimes submetidos aos sucos de laranja mostraram maior exposição da embocadura dos túbulos dentinários, 
comparativamente com os demais grupos. Dentre esses, o suco natural exerceu solubilização mais dramática da smear layer que o suco artificial. Efeitos progressivamente mais brandos foram observados, respectivamente, para os espécimes da Coca Colar regular e Coca Cola light, enquanto a Cerveja pouco alterou o que se encontra tipicamente nos espécimes com smear layer. Nesses últimos, os túbulos dentinários estão completamente obstruídos pelos resíduos do lixamento da superfície dentinária.

O que se conclui através dessas imagens é que o pouco que as bebidas testadas atuam sobre a superfície dos discos é suficiente para alterar os padrões de condutividade hidráulica da dentina. Aparentemente, não é necessário que os smear plugs sejam completamente removidos para que algum grau de permeabilidade seja registrado. Possivelmente, a pressão hidráulica empregada no presente trabalho $(720 \mathrm{~mm} / \mathrm{H} 2 \mathrm{O})$ é suficientemente forte para deslocar parcialmente o conteúdo dos túbulos e permitir a filtração da água.

Outros estudos têm demonstrado a capacidade de degradação do esmalte e da dentina pelo uso freqüente de Coca Cola. FUSHIDA e CURY, em $1999^{24}$, concluíram após estudo in vivo que, em função da freqüência de ingestão de Coca Cola, há alterações significativas da dureza e perdas proporcionais e irreversíveis da estrutura superficial tanto do esmalte como da dentina. Resultadas semelhantes, in vitro, foram obtidos por GEDALIA et al., $1991^{28}$.

Permitida a comparação do método aqui empregado com uma situação clínica de dentina exposta por degradação do esmalte, é fácil 
compreender o dramático efeito dos sucos e das "colas" na desobstrução dos túbulos e na indução da hiperestesia dentinária. Na boca, as lesões cervicais por erosão ou por outras etiologias têm, via de regra, a superfície dentinária desprovida de resíduos tão densos como a smear layer aqui ensaiada. Embora a ação neutralizadora da saliva deva ser clinicamente considerada, o consumo excessivo de bebidas com tais características pode levar à dissolução superficial das estruturas dentária. Além disso, o processo de erosão pode ser agravado pelo efeito mecânico do atrito ou da abrasão, pela escovação dos dentes ${ }^{61}$ e pela função mastigatória, respectivamente.

Feitas as considerações acima, destaca-se a importância da correta orientação dos pacientes no que diz respeito a seus hábitos alimentares e de higiene bucal, não somente para a prevenção de lesões dentárias por erosão mas, também, para controlar a evolução das lesões já instaladas. O dentista deve compreender que o tratamento da hiperestesia dentinária, independentemente do agente causador da sensibilidade depende fundamentalmente da eliminação dos fatores que causam as lesões dentárias de origem não cariosa. 
7- CONCLUSÕES 


\section{7- CONCLUSÕES}

Com base nos resultados obtidos pode-se concluir que:

1) as bebidas de teor ácido estudadas exerceram efeito sobre a condutividade hidráulica de dentina em diferentes graus, contrariando a primeira hipótese nula;

2) não houve diferença estatisticamente significante entre os valores condutividade hidráulica obtidos após 3 e 5 minutos, confirmando a segunda hipótese estabelecida;

3) os discos de dentina tratados com os refrigerantes e sucos apresentaram valores de condutividade hidráulica mais elevados do que as obtidas na presença de smear layer;

4) a Cerveja estudada não alterou significantemente a condutividade hidráulica dos discos de dentina;

5) para ambos os tempos estudados, os sucos de laranja exerceram efeito significantemente maior na condutividade hidráulica da dentina do que as bebidas do tipo "cola". Os efeitos destas e da Cerveja foram estatisticamente semelhantes. 
ANEXOS 


\section{Universidade de São Paulo \\ - Faculdade de Odontologia de Bauru -}

Al. Dr. Octávio Pinheiro Brisolla, 9-75 - Bauru-SP - CEP 17012-901 - C.P. 73 PABX (0XX14)235-8000 - FAX (0XX14)223-4679

Departamento de Dentística, Endodontia e Materiais Dentários e-mail : dep-demd@fob.usp.br -Fone: (0XX14) 235-8266

Bauru, abril de 2002.

\section{CARTA DE INFORMAÇÃO AO PACIENTE}

Senhor (a) paciente ou seu representante legal

A Faculdade de Odontologia de Bauru - USP desenvolve pesquisas científicas utilizando dentes extraídos. Por isso, quando o plano (proposta) de tratamento para o seu problema de dentes (sempre com acompanhamento de professores da FOB - USP) mostrar a necessidade de extração (arrancar) um ou mais dentes, solicitamos que o (a) senhor (a) faça a doação do(s) seu(s) dente(s) ou dos dentes do paciente que é representante legal.

Esta doação não é obrigatória, e o nome do doador não será divulgado. Caso não queira fazer a doação, o paciente não será excluído (retirado) do tratamento para o qual foi triado, anteriormente.

A doação não dará ao doador qualquer prioridade de tratamentos futuros, na Faculdade de Odontologia de Bauru - USP.

Obrigado por sua atenção.

"Caso o paciente apresente dúvidas ou reclamações em relação a sua participação na pesquisa, pode entrar em contato com Comitê de Ética em Pesquisa em Seres Humanos, da FOB-USP, pelo endereço Al. Dr. Octávio Pinheiro Brisolla, 9-75 (sala no prédio da Biblioteca, FOB-USP) ou pelo telefone (14)3235-8356". 


\section{Universidade de São Paulo}

- Faculdade de Odontologia de Bauru -

Al. Dr. Octávio Pinheiro Brisolla, 9-75 - Bauru-SP - CEP 17012-901 - C.P. 73

PABX (0XX14)235-8000 - FAX (0XX14)223-4679

Departamento de Dentística, Endodontia e Materiais Dentários

e-mail : dep-demd@fob.usp.br -Fone: (0XX14) 235-8266

\section{$\underline{\text { TERMO DE DOAÇÃO }}$}

$\mathrm{Eu}$, portador da

cédula de identidade de número autorizo a doação do (s) elemento (s) dentário (s) , à Faculdade de Odontologia de Bauru, FOB-USP, para a sua utilização em pesquisa científica.

Declaro-me ciente de que a doação não é obrigatória e de que não me dará qualquer prioridade para a realização de tratamentos futuros, na Faculdade de Odontologia de Bauru, FOB-USP.

Sem mais, firmo o presente.

Bauru, de de 2003.

Assinatura do Paciente ou Responsável legal 
Ficha para o registro dos dados obtidos nos ensaios da condutividade hidráulica e respectivos cálculos de Lp e porcentagem.

\section{CONDUTIVIDADE HIDRÁULICA}

Projeto: Ação de bebidas com potencial hiperestésico sobre a permeabilidade dentinária Estudo in vitro.

Data - Nome - Maria Cecília Disco: Espessura - mm
Capilar - $25 \mu \mathrm{l} 65 \mathrm{~mm}$
Área da Superfície: $\quad \mathrm{cm}^{2}$
Pressão - $703,1 \mathrm{~cm} \mathrm{H} \mathrm{H}_{2} \mathrm{O}$

Experimento -

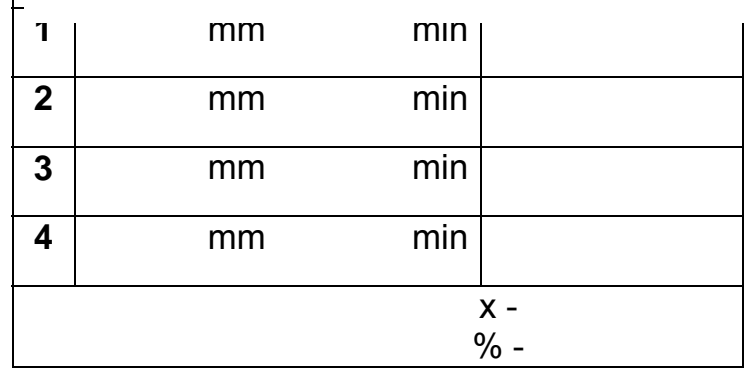

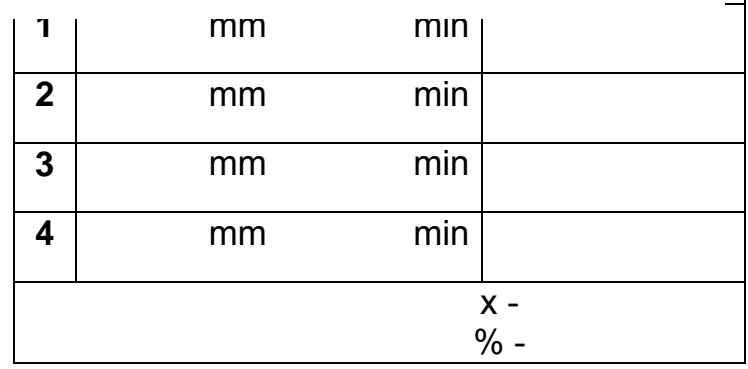

\begin{tabular}{|c|cr|l|}
\hline \multicolumn{2}{|c|}{ Condição: Materiall__ min. } & Lp \\
\hline $\mathbf{1}$ & $\mathrm{mm}$ & $\min$ & \\
\hline $\mathbf{2}$ & $\mathrm{mm}$ & $\min$ & \\
\hline $\mathbf{3}$ & $\mathrm{mm}$ & $\min$ & \\
\hline $\mathbf{4}$ & $\mathrm{mm}$ & $\min$ & \\
\hline \multicolumn{8}{|c|}{$\begin{array}{c}\mathrm{x}- \\
\%-\end{array}$} \\
\hline
\end{tabular}

\begin{tabular}{|c|cr|l|}
\hline \multicolumn{2}{|c|}{ Condição: Material/__ min. } & Lp \\
\hline $\mathbf{1}$ & $\mathrm{mm}$ & $\min$ & \\
\hline $\mathbf{2}$ & $\mathrm{mm}$ & $\min$ & \\
\hline $\mathbf{3}$ & $\mathrm{mm}$ & $\min$ & \\
\hline $\mathbf{4}$ & $\mathrm{mm}$ & $\min$ & \\
\hline \multicolumn{5}{|c|}{$\begin{array}{l}\mathrm{x}- \\
\%-\end{array}$} \\
\hline
\end{tabular}


REFERÊNCIAS BIBLIOGRÁFICAS 


\section{REFERÊNCIAS BIBLIOGRÁFICAS}

1 ADDY, M.; ABSI, E.G.; ADAMS, D. Dentine hipersensitivity - the effects in vitro of acids and dietary substances on root planed and burred dentine. J Clin Periodontol, v.14, n.5, p.274-9, May 1987.

2 ADDY, M.; MOSTAFA, P.; NEWCOMBE, R.G. Dentine hipersensitivity: the distribuition of recession sensitivity and plaque. J Dent, v.14, n.6, p.242-8, 1987.

3 AHLQUIST, M., et al. Dental pain evoked by hydrostatic pressures applied to exposed dentin in man: a test of the hydrodinamic theory of dentin sensitivity. J Endod, v.20, n.3, p.130-4, Mar 1994.

4 AZEVEDO, V.M.N.N. Avaliação de pacientes portadores de lesões dentárias cervicais não cariosas relacionadas com alguns aspectos físicos, químicos e mecânicos da cavidade bucal. Bauru, 1994. 103 p. Doutorado - Dentística Restauradora, Faculdade de Odontologia de Bauru, Universidade de São Paulo.

5 BERMAN, L.H. Dentine sensation and hipersensitivity - A review of mechanisms and treatment alternatives. J Periodont, v.56, n.4, p.216-22, 1985.

6 BHASKAR, S.N. Histologia e embriologia oral de Orban. São Paulo, Artes Médicas, v.10, 1989.

7 BHATTI, S.A.; WALSH, T.F.; DOUGLAS, C.W.I. Ethanol and pH levels of proprietary mouthrinses. Community Dent Health, v.11, p.71-4, 1994. 
8 BIRKHED, D. Sugar content, acidity and effect on plaque $\mathrm{pH}$ of fruit juice, fruit drinks, carbonated beverages and sport drinks. Caries Res, v.18, n.2, p.120-7, Mar/Apr 1984.

9 BISSADA, N.F. Symptomatology and clinical features of hipersensitivity teeth. Arch Oral Biol, v.39, p.31S-2S, 1994.

10 BRÄNNSTRÖM, M.; ASTRÖN, A. A study on the mecanism of pain elicited from the dentin. Dent Res, v.43, p.619-25, 1964.

11 BRÄNNSTRÖN, M. Sensitivity of dentine. Oral Surg, v.21, n.4, p.51729, 1966.

12 BRÄNNSTRÖN, M.; JOHNSON, G. Effects of various conditions and cleaning agents on prepared dentine surfaces: a scanning electron microscope investigation. J Prosth Dent, v.31, p.422-43, 1974.

13 BYERS, M.R.; NÄRHI, M.V.O. Dental injury models: experimental tools for understanding neuroinflammatory interactions and polymodal nociceptor functions. Crit Rev Oral Med, v.10, n.1, p.4-39, Feb 1999.

14 CAIRNS, A.M., et al. The $\mathrm{pH}$ and titratabel acidity of a range of diluting drinks and their potential effect on dental erosion. J Dent, v.30, n.7-8, p.313-7, Sept-Nov 2002.

15 CHABANSKI, M.B.; AL., E. Prevalence of cervical dentine sensitivity in a population of patients referred to a specialist periodontology department. J Clin Periodont, v.23, n.11, p.989-92, 1996.

16 COLLAERT, B.; FISCHER, C. Dentine hipersensitivity: a review. Endod Dent Traumat, v.7, n.4, p.145-52, Aug 1991. 
17 DAHL, E.; MJÖR, I.A. The structure and distribuition of nerves in the pulp-dentin organ. Acta Odont Scand, v.31, n.6, p.349-56, 1973.

18 DOWELL, P.; ADDY, M. Dentine hypersensitivity - A review. J Clin Periodont, v.10, n.4, p.341-50, 1983.

19 ECCLES, J.D.; JENKINS, W.G. Dental erosion and diet. J Dent Res, v.2, n.4, p.153-9, 1974 .

20 EDWARDS, M., et al. Buffering capacities of soft drinks: the potencial influence on dental erosion. J Oral Rehab, v.26, p.923-7, 1999.

21 ESTRELA, C. Ciência Endodôntica. São Paulo, Artes Médicas, 2004.

22 FITZGERALD, M.; CHIEGO, D.J.; HEYS, D.R. Autoradiographic analysis of odontoblast replacement following pulp exposure in primate teeth. Arch Oral Biol, v.35, n.9, p.707-15, 1990.

23 FRANK, R.M.; SAUVAGE, C.; FRANK, P. Morphological basis of dentine sensitivity. Int Dent J, v.22, n.1, p.1-19, 1972.

24 FUSHIDA, C.E.; CURY, J.A. Estudo in situ do efeito da frequencia de ingestão de Coca Cola na erosão do esmalte-dentina e reversão pela saliva. Rev Odontol Univ São Paulo, v.13, n.2, Apr-Jun 1999.

25 GANSS, C.; SCLECHTRIEMEN, M.; KLIMEK, J. Dental erosions in subjects living on a raw food diet. Caries Res, v.33, n.1, p.74-80, 1997.

26 GARBEROGLIO, R.; BRÄNNSTRÖM, M. Scanning electron microscopic investigation of human dentinal tubules. Arch Oral Biol, v.21, n.6, p.355-62, 1976. 
27 GARONE, W. Lesões cervicais e hipersensibilidade dentinária. In: Atualizações na Clínica Odontológica. São Paulo, Artes Médicas, 1996. 35-75 p.

28 GEDALIA, I.; IONAT-BENDAT, D.; BEN-MOSHEH, S. Tooth enamel softening with a cola type drink and rehardening with hard cheese or stimulated saliva in situ. J Oral Rehab, v.18, n.4, p.501-6, 1991.

29 GILLAM, D.G. Mechanisms of of stimulus transmission across dentin - a review. Periodontal Abstracts, v.43, n.2, p.53-65, 1995.

30 GILLAM, D.G.; MORDAN, N.J.; NEWMAN, H.N. The dentin disc surface: a plausible model of dentin physiology and dentin sensitivity evaluation. Advanc Dent Res, v.11, n.4, p.487-501, Nov 1997.

31 GOODIS, H.E.; MARSHALL, G.W.; WHITE, J.M. Post-extraction history effects on dentin permeability. Arch Oral Biol, v.36, p.561-6, 1991.

32 GOTJAMANOS, T. Mitotic activity in the subodontoblastic cell-rich layer of adult rat molar pulps. Arch Oral Biol, v.15, n.9, p.905-7, 1970.

33 GRANDO, L.J. Estudo in vitro da erosão causada por refrigerantes e suco de limão no esmalte de dentes decíduos humanos análises bioquímicas e morfológicas. Florianópolis, 1992Mestrado , Faculdade de Odontologia, Universidade Federal de Santa Catarina.

34 GREENHILL, J.D.; PASHLEY, D.H. The effects of desensitizing agents on the hydraulic conductance of human dentin in vitro. J Dent Res, v.60, n.3, p.686-98, 1981.

35 GRENBY, T.H., et al. Laboratory studies of the dental properties of soft drinks. Brit J Nutr, v.62, p.451, 1989. 
36 GROBLER, S.R.; JENKINS, G.N.; KOLTZE, D. The effects of the composition and method of drinking of soft drinks on plaque $\mathrm{pH}$. Brit Dent J, v.158, p.293-6, Apr 1985.

37 GROBLER, S.R.; VAN DER HORST, G. Biochemical analysis of various cool drinks with regard to enamel erosion, de-and remineralistion. $\mathbf{J}$ Dent Assoc South Afr, v.37, p.681, 1982.

38 HARGREAVES, K.M.; GOODIS, H.E. Seltzer and Bender's Dental Pulp. Chicago, Quintessence Publishing, 2002.

39 HOLLOWAY, P.J.; MELLANBY, M.; STEWART, R.J.C. Fruit drinks and tooth erosion. Brit Dent J, v.104, p.305-9, 1958.

40 HORIUCHI, H.; SCHWARTZ, B. In vitro observations on fluid flow through human dentine caused by pain-producing stimuli. Arch Oral Biol, v.18, p.275, 1973.

41 HUGHES, J., et al. Effects of $\mathrm{pH}$ and concentration of citric, malic and latic acids on enamel, in vivo. J Dent, v.28, n.2, p.147-52, Feb 2000.

$42 \mathrm{KIM}, \mathrm{S}$. Hipersensitivity teeth: desensitization of pulp sensoty nerves. J Endod, v.12, n.10, p.482-5, 1986.

$43 \mathrm{KIM}, \mathrm{S}$. Thermal stimuli in dentinal sensitivity. Endod Dent Traumatol, v.2, p.138, 1986.

44 KÖLING, A. Structural relationships in the human odontoblast layer, as demostraded by freeze-fracture electron microscopy. J Endod, v.14, n.5, p.239-46, 1988. 
45 LARSEN, M.J.; NYVAD, B. Enamel erosion by some soft drinks and orange juices relative to their $\mathrm{pH}$, buffering effect abd contents of calcium phosphate. Caries Res, v.33, n.1, p.81-7, 1999.

46 LEE, W.C.; EAKLE, W.S. Possible role of tensile stress in the etiology of cervical erosive lesion of teeth. J Prosth Dent, v.52, n.3, p.373-80, 1984.

47 LINKOSALO, E.; MARKKANEN, H. Dental erosions in relation to lactovegerarian diet. Scand J Dent Res, v.93, n.5, p.436-41, 1985.

48 LUSSI, A. Dental erosion - clinical diagnosis and case history taking. Eur J Oral Sci, v.104, p.191-9, 1996.

49 LUSSI, A.; JAEGGI, T.; JAEGGI-SCHÄRER, S. Prediction of the erosive potential of some beverages. Caries Res, v.29, p.349-54, 1995.

50 LUSSI, A.; JÄGGI, T.; SCHÄRER, S. The influence of diferent factors on in vivo enamel erosion. Caries Res, v.27, p.387-93, 1993.

51 MATHEW, T.; CASAMASSIMO, P.S.; HAYES, J.R. Relationship between sports drinks and dental erosion en 304 university athletes in Columbus, Ohio, USA. Caries Res, v.36, n.4, p.281-7, Jul-Aug 2002.

52 MATTHEWS, B.; VONGSAVAN, N. Interactions between neural and hydrodynamic mechanisms in dentine and pulp. Arch Oral Biol, v. v.39, n.Suppl, p.87S-95S, 1994.

53 MATTHEWS, W.G.; SHOWMAN, C.D.; PASHLEY, D.H. Air blast-induced evaporative water loss from human dentine, in vitro. Arch Oral Biol, v.38, n.6, p.517-23, 1993. 
54 MCDONALD, J.L.; STOOKEY, G.K. Laboratory studies concerning the effect of acid-containing beverages on enamel dissolution and experimental dental caries. J Dent Res, v.52, n.2, p.211-6, Mar/Apr 1973.

55 MERCHANT, V.A.; LIVINGSTON, M.J.; PASHLEY, D.H. Dentin permeation: comparison of diffusion with filtration. J Dent Res, v.56, n.10, p.1164-77, Oct 1977.

56 MILOSEVIC, A.; KELLY, M.J.; MC LEAN, A.N. Sports supplement drinks and dental health in competitive swimmers and cyclists. Br Dent J, v.182, n.8, p.303-8, Apr 1997.

57 MJÖR, I.A. Pulp-Dentin biology in restorative dentistry. Chicago, Quintessence, 2002.

58 MOAZZEZ, R.; SMITH, B.G.N.; BARTLETT, D.W. Oral pH and drinking habit during ingestion of a carbonated drink in a group of adolescents with dental erosion. J Dent, v.28, n.6, p.395-7, Aug 2000.

59 MONDELLI, J. Proteção do complexo dentino-pulpar. São Paulo, Artes Médicas, 1998. 316 p.

60 MOSS, S.J. Dental erosion. Int Dent J, v.43, n.6, p.529-39, Dec 1998.

61 NUNN, J.H. Prevalence of dental erosion and the implications for oral health. J Oral Sci, v.104, n.2, p.156-61, 1996.

62 ORCHARDSON, R., et al. Dentine hipersensibility into the 21st century. Arch Oral Biol, v.39, n.Supplement, p.113S-9S, 1994.

63 OUTHWAITE, W.C.; LIVINGSTON, M.J.; PASHLEY, D.H. Effects of cnangs in surface area, thickness, temperature and post-extraction 
time on human dentine permeability. Arch Oral Biol, v.21, n.10, p.599-603, 1976.

64 PASHLEY, D.H. Dentin permeability, dentin sensitivity, and treatment through tubule occlusion. J Endodon, v.12, p.465-74, 1986.

65 PASHLEY, D.H. Dentin permeability and dentin sensitivity. Proc Finn Dent Soc, v.88, n.1, p.31-7, 1992.

66 PASHLEY, D.H.; AL., E. Regional variability in the permeability of human dentine. Arch Oral Biol, v.32, n.7, p.519-23, 1987.

67 PASHLEY, D.H.; ANDRINGA, H.J.; EICHMILLER, F. Effects of ferric and aluminum oxalates on dentin permeability. Amer J Dent, v.4, n.3, p.123-6, 1991.

68 PASHLEY, D.H.; DEPEW, D.D. Effects of smear layer, copalite and oxalate on microleakage. Oper Dent, v.11, n.3, p.95-102, 1986.

69 PASHLEY, D.H.; GALLOWAY, S.E. The effects of oxalate treatment on the smear layer fo ground surfaces of human dentine. Arch Oral Biol, v.30, n.10, p.731-7, 1985.

70 PASHLEY, D.H.; LIVINGSTON, M.J.; GREENHILL, J.D. Regional resistence to fluid flow in human dentine in vitro. Arch Oral Biol, v.23, p.807-10, 1978.

71 PASHLEY, D.H.; LIVINGSTON, M.J.; WHITFORD, G.M. The effect of molecular size on reflection coefficients in human dentin. Arch Oral Biol, v.24, n.3, p.455-60, 1979.

72 PASHLEY, D.H.; MICHELIN, V.; T., K. Dentin permeability: effects of smear layer removal. J Prosth Dent, v.46, n.5, Nov 1981. 
73 PASHLEY, D.H.; WHITFORD, G.M. Permeability of human dentine in vivo interpreted from reflection coefficients. Arch Oral Biol, v.25, n.2, p.141-4, 1980.

74 PEREIRA, J.C. Hiperestesia dentinária. Aspectos clínicos e formas de tratamento. Maxi-Odonto : Dentística, v.1, n.2, p.1-24, Mar-Abr 1995.

75 PEREIRA, J.C., et al. Proteção do complexo dentino-pulpar. In: BUSATO, A. L. S. Dentística: Filosofia, conceitos e prática clínica. São Paulo, Artes Médicas, 2005. Proteção do complexo dentino-pulpar

76 PEREIRA, J.C.; SEGALA, A.D. Hipersensibilidade pós-tratamento restaurador. In: CARDOSO, R. J. A. G., E.A.N. Odontologia Laser e Dentística. São Paulo, Artes Médicas, v.1, 2002. Hipersensibilidade pós-tratamento restaurador

77 PEREIRA, J.C.; SEGALA, A.D.; GILLAM, D.G. Effect desensitizing agents on the hydraulic conductance of human dentin subjected to different surface pre-treatments - an in vitro study. Dent Mater, v.21, p.129-38, 2005.

78 PEREIRA, J.C., et al. Tratamentos conservadores da vitalidade pulpar: princípios biológicos e clínicos. Biodonto, v.2, n.3, p.1-105, 2004.

79 PEREIRA, J.C., et al. Avaliação clínica de quatro métodos de dessensibilização dentinária. Relat. CNPq. 1990. (802281/88-5) 
80 PINTO, C.O. Hiperestesia Dentinária. Bauru, 2002Monografia -

Dentística Restauradora, Faculdade de Odontologia de Bauru, Universidade de São Paulo.

81 PRATI, C., et al. Permeability and morphology of dentin after erosion induced by acidic dinks. J Periodont, v.74, n.4, p.428-36, Apr 2003.

82 PRATI, C., et al. Dentin morphology and permeability after brushing with different toothpastes in the presence and absence of smear layer. $\mathbf{J}$ Periodont, v.73, n.2, p.183-90, Feb 2002.

83 ROOS, E.H.; DONLY, K.J. In vivo dental plaque pH variation with regular and diet soft drinks. Pediatr Dent, v.38, n.4, p.350-3, Jul-Aug 2002.

84 RUGG-GUNN, et al. Comparasion of erosion of dental enamel by four drinks using an intra-oral applicance. Caries Res, v.32, n.5, p.337-43, 1998.

85 RYTÖMAA, J., et al. Dental erosion in relation to lactovegetarian diet.

Scand J Dent Res, v.96, n.4, p.324-33, 1988.

86 SCHAFFNER, M.; AL., E. Epidemiology of dental erosion and tooth brush abrasion. J Dent Res, v.66, n.Special Issue, p.338, 1988.

87 SEGALA, A.D. Efeito de agentes anti-hiperestésicos à base de oxalato de potássio na permeabilidade da dentina humana. Estudo in vitro. Bauru, 2000. 288 p. Mestrado - Dentística Restauradora, Faculdade de Odontologia de Bauru, Universidade de São Paulo.

88 SELTZER, S.; BENDER, I.B. A polpa dental. Rio de Janeiro, Editoral Labor Brasil, 1979. 
89 SHAW, L.; SMITH, A.J. Dental erosion - the problem and some practical solutions. Brit Dent J, v.186, n.3, p.115-8, Feb 1998.

90 SMITH, A.J.; MATTHEWS, J.B.; HALL, R.C. Transforming growth factor b1 (TGF-b1) in dentine matrix. Ligand activation and receptor expression. Eur J Oral Sci, v.106, n.suppl. 1, p.179-84, 1998.

91 SOBRAL, M.A.P. Aspectos clínicos da etiologia da hipersensibilidade dentinária cervical e avaliação clínica de algumas técnicas de tratamento. São Paulo, 1997. 142 p. -, Faculdade de Odontologia de São Paulo, Universidade de São Paulo.

92 SPIGSET, O. Oral symptoms in bulimia nervosa. Acta Odont Scand, v.49, n.6, p.335-9, 1991.

93 STAFINE, E.C.; LOVESTADT, S.A. Dissolution of tooth substance by lemon juice, acid beverages and acid from other sources. J Amer Dent Assoc, v.34, p.586-92, 1947.

94 STANLEY, H.R.; PEREIRA, J.C.; SPIEGEL, E. The detection and prevalence of reactive and physiological sclerotic dentin, reparative dentin and dead tracts beneath various types of dental lesions according to tooth surface and age. J Oral Path, v.12, n.4, p.257-89, 1983.

95 TELLES, D.M. Prevalência de lesões cervicais não cariosas em estudantes de odontologia e sua relação com aspectos oclusais. Bauru, 1997. 70 p. Mestrado -, Faculdade de Odontologia de Bauru, Universidade de São Paulo. 
96 TEN CATE, A.R. Histologia Bucal - desenvolvimento, estrutura e

função. 5. Rio de Janeiro, Guanabara, 2001.

97 TROWBRIDGE, H.O.; SILVER, D.R. A review of current approaches to in-office management of tooth hipersensibility. Dent Clin N Amer, v.34, n.3, p.561-81, 1990.

98 TURNER, D.F. Immediate physiological response of odontoblasts. Proc Finn Dent Soc, v.88, n.suppl. 1, p.55-63, 1992.

99 TZIAFAS, D.; SMITH, A.J.; LESOT, H. Designing new treatment strategies in vital pulp therapy. J Dent, v.28, n.2, p.77-92, Feb. 2000. 100 WICHGERS, T.G.; EMERT, R.L. Dentin hipersensitivity. Gen Dent, v.44, n.3, p.225-30, 1996.

101 WOTGENS, J.N.; AL., E. Enamel erosion and saliva. Clin Prev Dent, v.7, n.3, p.8-10, 1985.

102 YOSHIYAMA, M.; AL., E. Transmission electron microscopic characterization of hypersensitive human radicular dentin. J Dent Res, v.60, n.6, p.1293-7, Jun 1990.

103 YOSHIYAMA, M., et al. Scanning electron microscopic characterization of sensitive vs. insensitive human radicular dentin. $\mathbf{J}$ Dent Res, v.68, n.11, p.1498-502, 1989.

104 ZHANG, Y.; AL., E. The effects of pain free desensitizer on dentine permeability and tubule oclusion over time, in vitro. J Clin Periodont, v.25, n.11, p.884-91, 1998.

105 ZIPKIN, I.; MCCLURE, F.J. Salivary citrate and dental erosion. J Dent Res, v.28, p.613-26, 1949. 
ABSTRACT 


\section{ABSTRACT}

Dentine hipersensibility isn't an unusual pain condition in dentistry. However, although many researches have been made about the subject, its comprehension is still not clear. Hidrodynamic theory, which better explains the clinical situation, is based on dentinal fluid movement through dentinal tubules as a cause of pain. The study of the acidic drinks and its effects over tooth structures is much explored in the recent researches. The present study analyzed, in vitro, the dentine permeability changes to the exposition to regular Coca Cola, Coca Cola light, natural and artificial oranges juices and beer. Hydraulic conductivity test has been made in 50 dentine discs, divided into 5 groups, during 3 and 5 minutes of contact with each drink. The results were statistically analyzed with the Duncan test. The findings demonstrate that acidic drinks have an effect over the dentine hydraulic conductivity. More over, there isn't significance differences between hydraulic conductivity values after 3 and 5 minutes. In both intervals of time, orange juices provided an extremely effect over dentine hydraulic conductibility when compared with like cola drinks. Beer effects and like cola drinks were statistically similar. 